\title{
The Water-Energy-Food Nexus in East Asia: A Tele-connected Value Chain Analysis Using Inter-Regional Input-Output Analysis
}

by

David J. White ${ }^{\mathrm{a}}$, Klaus Hubacek ${ }^{\mathrm{a}, \mathrm{e}^{* 1}}$, Kuishuang Feng ${ }^{\mathrm{a}}$, Laixiang Sun ${ }^{\mathrm{a}, \mathrm{b}, \mathrm{c}}$, Bo Meng ${ }^{\mathrm{d}}$,

${ }^{\text {a }}$ Department of Geographical Sciences, University of Maryland, College Park, MD 20742, USA

b Department of Financial \& Management Studies, School of Oriental and African Studies, University of London, London, WC1H0XG, UK

c International Institute for Applied Systems Analysis, A-2361 Laxenburg, Austria

${ }^{d}$ Institute of Developing Economies, Japan External Trade Organization (IDE-JETRO), Chiba 2618545, Japan

e Department of Environmental Studies, Masaryk University, Brno, Czech Republic

* Corresponding authors: Hubacek@umd.edu 
Abstract

Population and economic growth pose unique challenges in securing sufficient water, energy, and food to meet demand at the sub-national (regional), national, and supra-national level. An increasing share of this demand is met through trade and imports. The unprecedented rapid growth, extent, and complexity of global value chains (GVCs) since the 1980s have reshaped global trade. The GVCs - and new economic patterns of regionalization - affect the demands on water, energy, and food within countries and across global supply chains. East Asia is of particular interest due to the region's rapid economic growth, substantial population size, high interdependence of the region's economies, and varying degree of resource availability. While greater interdependence across the region has increased the efficiency of production and trade, these activities require the input of water-energy-food and generate disturbances in the environment. The transnational inter-regional input-output approach is utilized in a tele-connected Water-Energy-Food Nexus (WEFN) analysis of the East Asia GVC to assess competing demands for these resources and environmental outcomes.

This analysis demonstrates the hidden virtual flows of water, energy, and food embodied in intraregional and transnational inter-regional trade. China's current national export oriented economic growth strategy in East Asia is not sustainable from the WEFN perspective. In terms of water-energy-food, China is a net virtual exporter to Japan and South Korea. China's prioritization of economic growth and trade in low value added and pollution intensive sectors consumes a great amount of water-energy-food within its territory to satisfy consumers' demands in Japan and South Korea. Japan's Kanto and Kinki regions and South Korea's Sudokwon region were the major beneficiaries while China bore the environmental burden associated with the production of exports. For example, net virtual exports from China's East region included over 1.2 billion $\mathrm{m}^{3}$ of scarce water and 61.3 million metric $\left(\mathrm{CO}_{2}\right.$ equivalent) tons of greenhouse gases (i.e. $\mathrm{CO}_{2}, \mathrm{NH}_{4}$, and $\mathrm{N}_{2} \mathrm{O}$ ) and 2 million metric tons of $\mathrm{SO}_{\mathrm{x}}$ emissions.

Trade is an important mechanism for overcoming resource bottlenecks, but, taking into account environmental linkages, regional specialization is not necessarily mutually beneficial. This analysis demonstrates a mismatch between regional water-energy-food availability and final resource consumption and the lack of attention for environmental impacts in national economic growth strategies. Resource scarce countries like China must, therefore, incorporate trade-off decisions between pursuing national economic growth, incurring environmental degradation, and food security into strategic regional development policies.

Keywords: Multi-regional input-output analysis, water scarcity, virtual water, footprint analysis, environmental indicators, $\mathrm{CO}_{2}$ equivalent, greenhouse gases 


\section{INTRODUCTION}

In today's globalized world, population increase and economic growth pose important challenges in securing sufficient water, energy, and food to meet demand at the sub-national (henceforth, regional), national, and supra-national level. East Asia is of particular interest due to the region's rapid economic growth, substantial population size, relatively recent regional economic structural transformation, and differing degree of resource availability and environmental pressures. The unprecedented rapid growth, extent, and complexity of global value chains (GVCs) since the 1980s have reshaped global trade and consumption of these three closely linked resources within and between countries (Gasiorek and Lopez, 2014). Policies for water, energy, and food - at the regional and national levels - have numerous interwoven challenges; including access to resources, environmental impacts, securing national priorities (e.g. economic growth), and national security. The inter-connectedness of the water, energy, and food subsystems has become ever more apparent as evidenced by the increasing application of the WaterEnergy-Food Nexus (WEFN) approach to identify tradeoffs and the search for cross-sector efficiencies to these challenges not only within countries but across global supply chains. With substantial quantities of commodities and services being traded across economic and ecosystem boundaries, an integrated assessment quantifying the virtually traded resources (and linked environmental pressures) of all three subsystems is needed in order to better understand the complexity of the WEFN and to adopt a comprehensive management approach. Furthermore, solving the issues of limited resource availability and sustainability requires an understanding of the integrated structure of the supra-national, national, and regional - see Figure 1 - economies in the context of the WEFN.

Over the past six decades, countries in the East Asia region have enjoyed some of the highest annual gross domestic product (GDP) growth rates in the world by pursuing independent export oriented trade policies; dominated by trade with the United States (World Bank, 2007). The People’s Republic of China, Japan, and the Republic of Korea (South Korea) each demonstrated 8\% to 10\% GDP growth rates for sustained periods of time; each achieving industrialization, urbanization, electrification, and motorization in the short span of 20 to 30 years (Pempel, 2013). The 1997-98 Asian Financial Crisis forced the East 


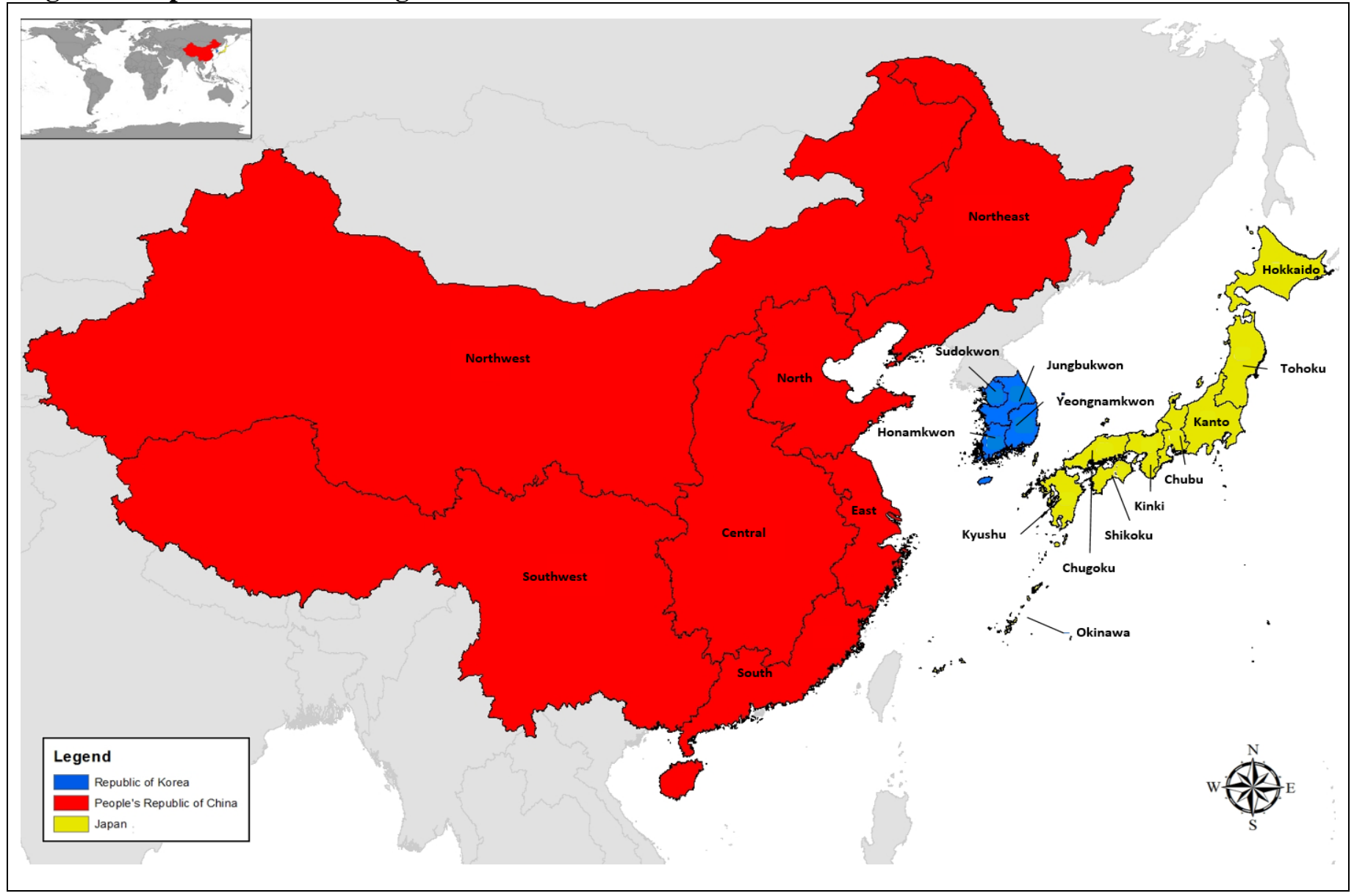

Asian countries to realign economic strategies and foster inter-regional economic cooperation - in the form of cross-border investments, financial coordination, trade, and inter-regional production networks - in order to avoid falling behind the European Union (EU) and North America GVCs (Aggarwal et al., 2008). The three economies became increasingly integrated and restructured the intra-industrial division of production and services to build up a highly interdependent network. China's accession to the World Trade Organization in 2001 resulted in a tremendous economic and political shift in the region. By 2005, the East Asia GVC had become established centered on China at its core (Yunling, 2010; ADB, 2014).

GVCs divide up the production of goods and services into linked stages of production distributed across international borders and economies. Instead of producing a product originating from a single factory, a product originates from a network of suppliers from multiple locations (ADB, 2014). China, as the manufacturing hub in East Asia's production networks, has been the main driving force increasing the interregional economic interdependence and an engine of economic growth. Over 50\% of China's export is 
composed of processing trade - i.e. raw materials, parts and components, technology and equipment, and economic services are exported from other East Asian economies to China for final processing and then exported to the U.S. and the EU. China's huge domestic market is also a source of export growth for neighboring countries for both manufactured products and primary commodities. Typically, this results in China possessing a substantial trade surplus with the U.S. and a considerable trade deficit with Japan and South Korea (Chiang, 2013; Kuroiwa and Ozeki, 2010). In 2005, China’s exports to Japan and South Korea totaled, respectively, $\$ 109.8$ billion and $\$ 31.8$ billion while imports were, respectively, $\$ 96.2$ billion and $\$ 66.7$ billion. There is a similar trade deficit between Japan and South Korea, Japan’s exports to and imports from South Korea were \$52 billion and \$25.9 billion (IDE-JETRO). China’s close production networks with Japan and South Korea - as well as its seemingly inexhaustible pools of low-wage workers and abundant raw materials - have allowed China to become the world's largest manufacturer and exporter (Gereffi, 2014). These inter-regional production networks have implications on demand for water-energyfood and ecosystems.

Recently, the WEFN approach has become an increasingly popular perspective among scholars. A 'nexus' among water-energy-food was conceived by the World Economic Forum to highlight the inseparable linkages between the use of resources and the universal human rights to water, energy, and food security (WEF, 2011). For example, water is consumed for the production of food and energy (e.g. fossil fuel processing, biofuels) and energy is necessary to transport, treat, and distribute water, fuel farming equipment, and manufacture chemical inputs necessary for agriculture production. The WEFN concept is based on systematic analysis of the interactions between the natural environment and human activities in order to better understand and to work towards a more balanced use of natural resources (FAO, 2014).

Early WEFN publications typically only analyzed two of the three subsystems in a nexus relationship: water-food nexus (see Brown and Halweil, 1998; Hoekstra and Hung, 2005; Dalin et al., 2014; Antonelli and Tamea, 2015; Vanham, 2016), food-energy nexus (see Karkacier and Goktolga, 2005; Abdelradi and Serra, 2015), and water-energy nexus (see Scott et al., 2011; Hardy et al., 2012; Pfister et al., 2012; Walker et al., 2013; Vilanova and Balestieri, 2015; Murrant et al., 2015; Pradeleix et al., 2015; Gua et al., 2016; Vieira and Ghisi, 2016; Wong and Pecora, 2016). Current WEFN publications have become more 
sophisticated and capable of investigating all three subsystems: for example, biomass or biofuel crop production (see Gerbens-Leenes et al., 2009; Bazilian et al., 2013; Miara et al., 2014; Mirzabaev et al., 2015), future impact scenarios of climate change on WEFN (see Ringler et al., 2016), incorporating satellite remote sensing analysis to assess the WEFN (see review by Sanders and Masri, 2016), modeling waterenergy-food interdependencies and management (Bazilian et al., 2011; Daher and Mohtar, 2015; Al-Ansari et al., 2015; Zimmerman et al., 2016; Zhang and Vesselinov, 2017), and the consumption of water and energy in the production of greenhouse tomatoes in Spain (Irabien and Darton, 2016).

While the nexus concept has been widely embraced, it is not a clearly defined construct or fully tested in practice (Wichelns, 2017). Despite not possessing a defined framework or a universal set of sectors to be analyzed, the concept has encouraged a wide range of approaches in a variety of WEFN contexts; for example, critical emphasis on particular subsystems including water (Vanham, 2016), food security (de Laurentiis et al. 2016), climate change (Ringler et al., 2013; Berardy and Chester, 2017), and so forth. A criticism of the nexus concept has been the lack of a clear definition of integration within the nexus which makes it difficult to establish what constitutes a 'successful' nexus analysis; creating significant challenges to developing nexus-orientated strategies. In other words, how to implement the WEFN and deliver real world solutions has proven difficult (Leck et al., 2015; Wichelns, 2017).

In general, ecosystems have been the ignored dimension of the nexus (i.e. over-using, depleting, and polluting unvalued or under-valued environmental resources and services) (see Vora et al., 2017), but ecosystems underpin each of the three nexus subsystems and the services they provide. Ecosystem degradation can undermine energy access, the availability of water, and food production, thereby impacting human health and livelihoods. Taking an integrated view of such interlinked issues is highly challenging given that nexus issues manifest themselves in different ways in the context of individual countries with differing resource and technology endowments, governance and development trajectories. Therefore, a 'successful' approach to resource management and sustainable development must be one that is capable of quantifying flows and inter-dependencies of water, energy, and food and environmental pressures at various scale. 
The objective of this paper is to clarify the tele-connected supra-national structure of the WEFN and environmental linkages between the three subsystems and examine the impacts and tradeoffs between each subsystem across scale. The term teleconnections is used to describe the spatial linkages between local consumption and environmental impacts over large distances (Yu et al., 2013; Hubacek et al., 2014). This paper incorporates the environmental indicators water scarcity and $\mathrm{CO}_{2}, \mathrm{CH}_{4}, \mathrm{~N}_{2} \mathrm{O}$, and $\mathrm{SO}_{\mathrm{x}}$ emissions. The major greenhouse gases $\mathrm{CO}_{2}, \mathrm{CH}_{4}$, and $\mathrm{N}_{2} \mathrm{O}$ (henceforth, GHG) caused by human activities have global implications contributing to the warming of the planet (USEPA, 2017). The group of sulfur oxide $\left(\mathrm{SO}_{\mathrm{x}}\right)$ gases - including the component of greatest concern sulfur dioxide $\left(\mathrm{SO}_{2}\right)$ - is emitted primarily from the burning of fossil fuels by power plants, industry, and shipping. $\mathrm{SO}_{\mathrm{x}}$ is a pollutant whose effects are felt locally. Exposure to $\mathrm{SO}_{\mathrm{x}}$ has been linked to respiratory illnesses in humans, damage to plant foliage and growth, and is an important acid rain precursor (ibid, 2017). A tele-connected WEFN approach is applied to investigate regional water, energy, and food consumption, the competing domestic and international demand for these resources, and the linked environmental pressures in East Asia's transnational interregional trade by modelling data contained in the Transnational Interregional Input-Output Table (TIOT) - which includes production, consumption, and trade flows between China, South Korea, and Japan - for the year 2005 (IDE-JETRO).

\section{DATA AND MeThodology}

The concept of ‘virtual’ trade originates from J. Anthony Allan’s (1994) discussion of ‘virtual’ water. The term 'virtual' extends beyond the water physically contained in the product to include the resource 'embodied' in products and used in the whole production chain of goods and services. Over time, the application of the 'virtual' concept in the research literature has expanded to include quantifying a variety of resources required to produce any commodity or associated pollution byproducts (Fang et al., 2014). The 'virtual trade flow' is the embodied resource traded between regions or exported to foreign countries. The concept of the 'footprint' originates from the idea of the ecological footprint (see Rees, 1992). The footprint captures the total amount of a resource that is used to produce the goods and services consumed by an individual or nation; within its spatial boundaries and embodied within its imports (Daniel et al. 2011). 
There are two approaches in virtual trade accounting: "bottom-up” and “top-down”. The Life Cycle Assessment (LCA) is a "bottom-up" approach that defines the system boundary at various scale and then assesses the overall resource consumption using detailed descriptions of individual production processes. The LCA has the ability to provide detailed process analysis on specific products, but requires huge amounts of data for multiple commodities (e.g. several thousand). Input-output analysis (IOA) is a 'top-down' approach that begins at the highest level defined by the system boundary and then breaks down to lower levels according to further defined sub-boundaries. Feng et al. (2011) compared the top-down versus bottom-up approaches and determined the IOA possesses several advantages: able to distinguish between intermediate and final users; scalable and capable of tracing entire regional, national, or global supply chains; includes both direct and indirect consumption throughout the supply chain; and, avoids the 'bottomup’ truncation error.

Environmental input-output analysis (EIOA) incorporates environmental indicators to measure different aspects of an economy in an integrated and systematic approach. This paper adopts the term 'environmental pressures’ promoted by the European Union to refer to the environmental indicators (i.e. scarce water and GHG and $\mathrm{SO}_{\mathrm{x}}$ emissions) in the analysis to show the pressures which human activities place on the environment (European Communities, 2001). Furthermore, in this study the agriculture land use indicator represents land displaced from food production. EIOA is able to trace multiple environmental impacts driven by production of infinite order, between sectors within an economic region and between regions, and, therefore, capable of analyzing the tele-connected interactions between the environment, economic, and social systems (Hubacek et al., 2009). Within the last decade, the EIOA has been extended to evaluating various human-induced effects on resources and the environment: e.g., scarce water (Feng et al., 2014a; Lenzen et al., 2013); water pollution (Okadera et al., 2006); $\mathrm{CO}_{2}$ (Du et al., 2011; Feng et al., 2013); emergy (Cho, 2013); ecological and water footprints (Hubacek et al., 2009; Ewing et al., 2012); land, carbon, and water (Lee, 2015).

EIOA studies focusing on the WEFN are rare. One exception is Karkacier and Goktolga (2005) study on the energy-food interlinkages in Turkey utilizing IOA modelling to explicitly analyze the interdependency between the agriculture and energy sectors. Li et al. (2012) applied an EIOA-LCA hybrid 
model to evaluate water consumption and $\mathrm{CO}_{2}$ emissions from China's wind power sector. Their waterenergy nexus study determined the water required for wind power generation and incorporated an environmental indicator for $\mathrm{CO}_{2}$ emissions. Holland et al. (2015) global water-energy nexus study investigated the impact of nations’ energy demands on freshwater resources utilizing a global multi-regional input-output (MRIO) model - including 129 countries/regions - to measure the total freshwater consumption along global supply chains.

\subsection{Multi-Regional Input-Output Modeling (MRIO)}

The IOA is based on data contained in input-output tables. Each entry in the $i$-th row and $j$-th column illustrates the flow from the $i$-th sector to the $j$-th sector. The IOA consists of $N$ linear equations depicting the production of an economy represented in Eq. (1):

$$
X_{i}=\sum_{j=1}^{N} Z_{i j}+y_{i}
$$

where $N$ is the number of sectors in an economy; $x_{i}$ is the total economic output of the $i$-th sector; $y_{i}$ is the final demand of sector $i . z_{i j}$ is the monetary flow from the $i$-th sector to the $j$-th sector.

The MRIO model extends the standard IOA matrix to a larger economy that includes each industry in each country or region possessing a separate row and column. The MRIO represents the complete inputoutput interactions of the defined economy.

The matrix of intermediate use coefficient can be calculated directly by Eq. (2):

$$
\boldsymbol{A}^{r s}=\left(a_{i j}^{r s}\right)=\left(z_{i j}^{r s} / x_{j}^{S}\right)
$$

where $z_{i j}^{r s}$. represents the inter-sector flow from the $i$-th sector in region $r$ to $j$-th sector in region $s . x_{j}^{s}$ is the

total output of $j$-th sector in region s. Assume that the total number of regions is $R$ and the total number of final demand categories is $F$, the economy wide sectoral output is a vector $(N R \times 1)$ and can be shown as Eq. (3):

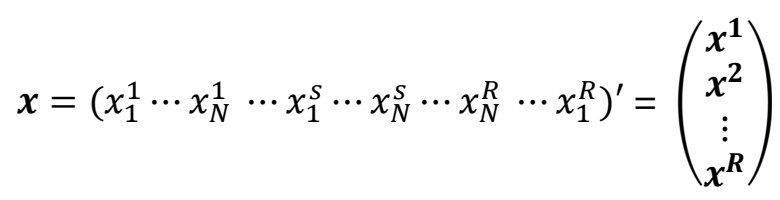

The final demand matrix $(N R \times F)$ can be shown as Eq. (4): 


$$
Y=\left(y^{r, f}\right)=\left(\begin{array}{cccc}
y^{1,1} & y^{1,2} & \cdots & y^{1, F} \\
y^{2,1} & y^{2,2} & \cdots & y^{2, F} \\
\vdots & \vdots & \ddots & \vdots \\
y^{R, 1} & y^{R, 2} & \cdots & y^{R, F}
\end{array}\right)
$$

where $\boldsymbol{y}^{\boldsymbol{r}, \boldsymbol{f}}$ represents the $f$-th category of final demand vector in region $r$. The total final demand vector $(\boldsymbol{y})$ is the sum of the following five categories in this research: household consumption, government expenditure, capital formation, changes of inventory, and international export. Eqs. (1)-(4) can be written in a matrix form as follows.

$$
\left(\begin{array}{c}
x^{1} \\
x^{2} \\
\vdots \\
x^{R}
\end{array}\right)=\left(\begin{array}{cccc}
A^{11} & A^{12} & \ldots & A^{1 R} \\
A^{21} & A^{22} & \cdots & A^{2 R} \\
\vdots & \vdots & \ddots & \vdots \\
A^{R 1} & A^{R 2} & \ldots & A^{R R}
\end{array}\right)\left(\begin{array}{c}
x^{1} \\
x^{2} \\
\vdots \\
x^{R}
\end{array}\right)+\sum_{f}\left(\begin{array}{c}
y^{1, f} \\
y^{2, f} \\
\vdots \\
y^{R, f}
\end{array}\right)
$$

where the coefficient matrix $\boldsymbol{A}(N R \times N R)$ represents the intermediate input matrix across sectors and regions. Vector $\boldsymbol{x}$ represents total output of each economic sector in each region.

The mathematical structure can be re-written as Eq. (6):

$$
x=\mathbf{A x}+y
$$

The Leontief inverse $\boldsymbol{L}$ matrix $(\boldsymbol{I}-\boldsymbol{A})^{-1}$ captures both direct and indirect inputs required to satisfy one unit of final demand. Solving for $\boldsymbol{x}$ results in Eq. (7):

$$
x=(I-A)^{-1} y
$$

where $\boldsymbol{I}$ is the identity matrix. Please note that Eq. (7) can be driven by an individual category of final demand to derive total sectoral outputs that are necessary for satisfying this given category of final demand.

The MRIO table is extended with environmental coefficients of different environmental indicators. In order to capture both the direct and indirect resource consumption and emissions, the matrix of environmental-impact coefficients $\boldsymbol{K}$ (by environmental category, by sector, and by region) are multiplied with the Leontief matrix $\boldsymbol{L}$ and final demand vector $\boldsymbol{y}$, as presented in Eq. (8):

$$
T=K(I-A)^{-1} y
$$

where $\boldsymbol{T}$ is a matrix representing different environmental-impact indicators. In matrix $\boldsymbol{K}$, each element, $k_{j}^{r, e}$, represents direct impact on environmental category $e$ caused by per unit of economic output of sector $j$ in region $r$. 
The environmental coefficients $k_{j}^{r, e}$ are assumed to be fixed within the specified period of time. The environmental categories we focus in this research include water $\left(\boldsymbol{K}_{\boldsymbol{c}}\right)$, scarce water $\left(\boldsymbol{K}_{s}\right)$, energy $\left(\boldsymbol{K}_{\boldsymbol{e n}}\right)$, and agricultural land use $\left(\boldsymbol{K}_{\boldsymbol{a l}}\right)$ and the generation of $\mathrm{CO}_{2}\left(\boldsymbol{K}_{\mathrm{CO} 2}\right), \mathrm{CH}_{4}\left(\boldsymbol{K}_{\boldsymbol{C H} 4}\right), \mathrm{N}_{2} \mathrm{O}\left(\boldsymbol{K}_{N 2 O}\right)$, and $\mathrm{SO}_{\mathrm{x}}\left(\boldsymbol{K}_{\text {sox }}\right)$ air pollution.

This paper adopts the Water Stress Index (WSI) concept as defined and advanced by Pfister et al. (2009). Focus is placed on the effects of consumptive water use as a function of total water availability. The water use to availability ratio (WTA), $W T A_{m}=\sum_{n} W U_{m n} / W A_{m}$, is calculated for each watershed $m$. Where $W A_{m}$ is the annual freshwater availability and $W U_{m n}$ is withdrawals for use $n$ in watershed $m$. WTA is WTA in watershed $m$. Use categories include industry, agriculture, and households. Pfister et al. (2009) applied a logistic curve to represent thresholds for water stress levels at continuous values between 0.01 and 1 in Eq. (10):

$$
\mathrm{WSI}=\frac{1}{1+e^{-6.4 \cdot \mathrm{WTA}^{*}}\left(\frac{1}{0.01}-1\right)}
$$

where WTA* is the weighted ratio of annual freshwater withdrawals for different users (i.e. industry, agriculture, and households) to annual freshwater availability calculated for each basin watershed accounting for annual and monthly precipitation variability and flow regulation by basin. The distribution curve is adjusted to result in a WSI of 0.5 for a WTA of 0.4 so that the threshold between moderate and severe water stress is expressed as the median value; i.e. a WSI value greater than 0.5 represents a severely stressed area. The WSI concept indicates the portion of water consumption that deprives freshwater to other users - or degree of 'water deprivation' - to indicate the pressure on renewable water resources. The WSI describes water stress at a high spatial resolution of $0.5^{\circ}$. Water scarcity weighting, $\boldsymbol{K}_{\boldsymbol{s}}$, is incorporated into the calculation based on Eq. (8) to account for scarce water in the virtual water flow and thus to reflect the scarcity of the water being used.

\subsection{Data}

IDE-JETRO’s 2005 TIIOT contains regional economic flows between China (seven regions), South Korea (four regions), and Japan (nine regions) aggregated into fifteen sectors (see SI). The TIIOT also includes “other” countries (i.e. Taiwan, ASEAN5, United States) not incorporated into the WEFN analysis. 
The TIIOT links the sub-national (i.e. regional) inter-regional input-output tables of China, Japan, and South Korea into a single matrix using the bilateral trade data provided by the individual countries (sources: State Information Center of China, Bank of Korea, and IDE-JETRO). The table permits analysis of the economic linkages across borders and mapping the cross-national production networks in East Asia at the regional scale. The TIIOT was extended with satellite accounts for water, energy, agriculture land use, scarce water, and GHG and $\mathrm{SO}_{\mathrm{x}}$ emissions for each sector.

Water consumption was estimated based on the sectoral water withdrawal of each province within the region multiplied by the ratio of water withdrawal to water consumption in the agricultural, industrial, service and domestic sectors of that province. Water consumption is defined as water use that is not returned to the original water source after being withdrawn; consequently unavailable for other users within a given time period. Only 'blue water' in million $\mathrm{m}^{3}$ was analyzed due to the data availability and its relevance to water policy. China's water consumption ratios for the year 2008 were estimated based on official Water Resource Bulletins for river basins (e.g., Yellow River Water Resource Bulletin) and provincial Water Resource Bulletins (e.g., Liaoning Water Resource Bulletin). Additional economic and environmental data was obtained from official publications (e.g., Beijing Statistical Yearbook 2009). South Korea’s 2005 water consumption ratios were obtained from the Ministry of Land Transportation, Water Resources, and Policy Bureau, Statistics Korea, and WIOD. Japan's 2007 water consumption ratios were obtained from the Research and Statistics Department, Minister's Secretariat Ministry of Economy, Trade and Industry, provincial water statistics (i.e. Niigata, Nagano, Shizuoka, and Fukui), and the Ministry of Land, Infrastructure, Transport, and Tourism.

To explicitly consider the impact of water extraction, we incorporate the water stress index (WSI) as an indicator of water scarcity. The WSI calculation for each region in China, Japan, and South Korea was applied according to Pfister et al. (2009) methodology to account for virtual scarce water flows to reflect the scarcity of the water being used. In other words, the WSI weighting converts total water use into scarce water use.

The data for Japan, China, and South Korea analyzing the food (land unit: hectare) and energy (unit: terajoule) subsystems and $\mathrm{CO}_{2}, \mathrm{CH}_{4}$, and $\mathrm{N}_{2} \mathrm{O}$ (unit: $\mathrm{CO}_{2}$ equivalent metric ton) and $\mathrm{SO}_{\mathrm{x}}$ (unit: metric ton) 
emissions were obtained from the World Input-Output Database (WIOD). All GHG emissions were converted into $\mathrm{CO}_{2}$ equivalents to permit comparison. Each GHG has a different global warming potential (GWP) and persists in the atmosphere for different lengths of time. This paper follows the 100-year GWP for greenhouse gases reported by the United Nations Framework Convention on Climate Change: carbon dioxide (1x), methane (25x), and nitrous oxide (298x) (UNFCCC, 2007). Agricultural land use data were obtained from 2005 WIOD agriculture land accounts. The displacement of agriculture land is used as a proxy for the food subsystem of the WEFN. Total land consumed for the agriculture sector consisted of arable land, permanent crops, and pasture land types. Energy and GHG and $\mathrm{SO}_{\mathrm{x}}$ emissions were obtained from 2005 WIOD accounts. WIOD data for energy and $\mathrm{CO}_{2}$ emissions consisted of 25 sources which were consolidated into nine: coal, oil, gas, hydropower, geothermal, solar, wind, nuclear, and biofuels.

In this study, we aggregated WIOD’s 36 sectors to match with the TIIOT’s 15 sectors at the national level; utilizing IDE-JETRO's expanded 76 intermediate sector classification table as reference for aggregation (see SI). For example, WIOD ‘food, beverages, and tobacco’, 'leather and leather footwear', and 'wood and products of wood' sectors were consolidated into the 'other non-electrical consumption products for daily-use' sector. In order to analyze WIOD’s national level energy, land, and GHG and $\mathrm{SO}_{\mathrm{x}}$ emissions data at the sub-national (i.e. regional) level, a proportional scaling was applied for each region and sector. To match these data with regions in East Asia, we disaggregated the respective national data to the seven China, nine Japan, and four South Korea regions according to their sectorial economic output. This scaling method assumes that the environmental pollution and resource consumption per unit of output (i.e. environmental coefficients) for a region are the same as at the national level.

Regional and national population data for 2005 was obtained from National Bureau of Statistics of China, the Statistics Bureau of Japan, Ministry of Internal Affairs and Communication, and Statistics Korea.

\subsection{Limitations}

IDE-JETRO’s 2005 TIIOT contains bilateral trade between China, South Korea, and Japan as well as “other” countries (i.e. Taiwan, ASEAN5, and the United States). Water-energy-food and environmental pressure coefficients were incorporated into the analysis for China, South Korea, and Japan. The environmental footprints for China, Japan, and South Korea does not include imported water-energy-food 
and pollution offloading data from "other" countries. However, the MRIO analysis of the TIIOT does include China, Japan, and South Korea exports of water-energy-food and pollution generation to the "other" countries; domestic environmental implications and water-energy-food exports to the "other" countries are not included in the Results section.

The IDE-JETRO TIIOT is for the year 2005. The age of the data is a significant shortcoming. However, the 2005 TIIOT is the most current region-specific dataset for East Asia. The 2005 TIIOT has two distinct advantages. First, the TIIOT’s regional data specific to East Asia permits an analysis of the harmonized transnational inter-regional data of virtual trade in resources and environmental pressures at the supranational to region and region to region level between China, Japan, and South Korea. There exist more current global multi-regional input-output (GMRIO) databases (see Tukker and Dietzenbacher, 2013), but a major shortcoming of the GMRIO databases is the lack of detailed trade flow data below the national level, i.e. between regions. Recently, several methodologies have been developed (see Bachmann et al., 2015; Wenz et al., 2015; Wang et al., 2015) which permit multiple spatial scales (i.e. global, supra-national, national, regional, etc.) to be incorporated into an analysis; i.e. capturing the heterogeneity of regions within the global economy. However, the disadvantage of these approaches is increased data inaccuracy due to the disaggregation approximations of trade flows from one region in one country to a region in another country. Second, the TIIOT permits a unique window into the development of the East Asia GVC - prior to the 2008-9 global economic crisis - and the inter-regional production networks centered around China as the 'factory of the world' (Gereffi, 2014).

The limitations of IOA are well documented in the literature. For a summary, see for example Wiedmann (2009), Lenzen et al. (2010), Daniels et al. (2011), and Wiedmann et al. (2011). This paper applies the standard MRIO which does not have the ability to measure the impact of individual products. An alternative approach with higher sectoral resolution - such as the input-output assisted hybrid life cycle assessment (see Suh, 2004; Li et al., 2012) - was not utilized as the MRIO is the appropriate model for this investigation of the East Asia region. MRIO analysis provides only a 'snapshot' of the state of an economy during a single accounting period, generally a year. This research shares shortcomings particular to all IOA studies in regards to data uncertainty due to sectoral aggregation error (see Lenzen, 2011; Steen-Olsen et 
al., 2014). Data aggregation uncertainty exists due to the highly aggregated 15 sector TIIOT. For the energy and GHG and $\mathrm{SO}_{\mathrm{x}}$ air pollution data obtained from the 36-sector WIOD, the correspondence between the WIOD data and the TIIOT was many-to-one; resulting in greater aggregation of data. The water coefficient data sectors had variable sector count (not including direct household consumption) depending on the country and data source; i.e. Japan 24-sector, China 30-sector, and South Korea 12-sector. Japan’s and China's water data were aggregated to 15 sectors and, due to the fact that water data for South Korea had fewer sectors than the TIIOT, it was necessary to disaggregate the water data to the corresponding TIIOT sectors according to their sectoral economic output. This was done by assuming that the sectorial water intensity in the corresponding TIIOT sectors was the same as the intensity of the more highly aggregated original water data. Regarding aggregation at the sector level, for example, all agriculture is aggregated into one "agriculture” sector; including water intensive livestock, aquaculture, fruits, rice, and etc. production as well as lower water intensive agriculture crops. Averaging natural resource requirements for all crops and sectors under 'agriculture' may under- or over-estimate the water requirements and, therefore, the virtual flows in the East Asia transnational inter-regional trade (Daniels et al., 2011).

Directly measuring food production and consumption in this MRIO WEFN analysis is challenging; i.e. developing a satellite account of food consumption coefficients would require a comprehensive database of the East Asian region's food consumption preferences and trends. This study incorporates agriculture land use data as a proxy for food production and consumption and trade across the East Asia region. The association of food production and consumption with the agriculture land use coefficient as a proxy has limitations in its application. First, the agriculture land use coefficient consists of the land types arable land, permanent crops, and pastures; which include a broad spectrum of food and non-food (e.g. wool) agriculture products. Second, as noted earlier in this section, due to aggregation of data under the 'agriculture' sector (i.e. inclusion of highly land intensive as well as low land intensive agriculture) there is the possibility for over-estimating the land use coefficient for food production and consumption. Third, this study does not have the ability to account for multiple and simultaneous uses of agriculture land, but that is a common problem of IO analysis using physical land coefficients.

\section{REsults}




\subsection{Direct Water-Energy-Food and Environmental Pressures}

In the water-energy linkage, water is necessary for energy extraction, conversion, transport and power generation (Siddiqi and Anadon, 2011). Water consumption for fossil energy (e.g. coal, crude oil, natural gas) extraction varies by geographical features and extraction technologies. All types of energy generation require water, but the amount of water needed is determined by thermal efficiency, heat sink accessibility, cooling systems, and the type of power plant. Thermoelectric forms of electricity generation include coal, oil, natural gas, and nuclear (Chang et al., 2016; WEF, 2008). Thermal power plants constitute almost 80\% of electricity generation worldwide. All thermoelectric plants that use steam turbines require water for cooling. Regardless of the fuel source, cooling is responsible for $80 \%$ to $90 \%$ of the water consumed in thermoelectric plants. There is a large range of results in the literature regarding the amount of water required by each form of energy generation technology. In terms of direct water withdrawals per unit of electricity production, nuclear is the largest and natural gas fired the least water consuming thermoelectric technology; solar and wind power systems consume almost no water for generating electricity (WEF, 2008; IEA, 2012; Tan and Zhi, 2016). Recently, there have been an increasing number of publications that calculate both direct water consumed and embodied water from all upstream inputs required by sector (e.g. oil extraction, oil refining, steel and concrete production for structures, crops for biofuel) to meet final energy demand (see Li et al., 2012; Holland et al., 2015; Feng et al., 2014b). For example, Feng et al. (2014b) analysis of the total life cycle water consumption (i.e. net amount of water consumed along the supply chain to produce $1 / \mathrm{kWh}$ of electricity) estimated that biomass and hydropower were the most waterintensive forms of energy generation, followed by coal, oil, nuclear, natural gas, solar, and wind. The water footprint of crops such as sugarcane, maize, and soybean is significantly higher than that of fossil energy generation (Chang et al., 2016; Tan and Zhi, 2016). Taking into account the increase in water evaporation from dammed reservoirs, hydroelectric power generation is a significant water consumer in the waterenergy linkage; additionally, dams may alter the timing of stream flows and conflicts may arise during periods of severe water shortage over water flow (Yillia, 2016).

Direct water consumption for electricity generation was the third largest consumer of water in China (16.3 billion $\mathrm{m}^{3}$; $6 \%$ of national water consumption) and South Korea (900 million $\mathrm{m}^{3} ; 21 \%$ ). Electricity 
generation was the second largest consumer of water in Japan (18.1 billion $\mathrm{m}^{3}$; 18\%). National consumption of energy was 50.9 million TJ in China, 18.7 million TJ in Japan, and 7.3 million TJ in South Korea. Japan's and South Korea's consumption had an expected higher water requirement per kilowatt generated as a greater proportion of national electricity was obtained from water-intensive nuclear technology. In comparison, China's substantially larger and less water-intensive national electricity consumption was obtained primarily from coal. The proportion of national electricity generation from different technologies were the following: China (coal 90\%, hydropower 5\%, oil 2\%, nuclear $2 \%$, gas $1 \%$ ), Japan (nuclear 32\%, gas $28 \%$, coal $24 \%$, oil $12 \%$, hydropower $3 \%$, geothermal $1 \%$ ), and South Korea (nuclear $43 \%$, coal $36 \%$, gas $13 \%$, oil $8 \%)$.

The water-food linkage mainly refers to the water required for agricultural products (e.g. livestock, crops). Animal products have a much larger water requirement compared to crops per calorie unit (Chang et al., 2016). Food production in China was the largest direct water consumer in East Asia totaling 223.4 billion $\mathrm{m}^{3}$ (77\% of national water consumption). Nationally, food production in Japan and South Korea were similarly the largest direct water consumers accounting for, respectively, 54.7 billion $\mathrm{m}^{3}$ (55\%) and 1.7 billion $\mathrm{m}^{3}$ (40\%). The national food subsystem by land type consisted of the following: China's 118.3 million hectare (ha) (22.3\%) arable land, 12.5 million ha (2.4\%) permanent crops, and 400 million ha (75.4\%) pasture; Japan’s 4.3 million ha (93\%) arable land, 324 thousand ha (7\%) permanent crops, and 0 ha pasture; and South Korea’s 1.6 million ha (87.4\%) arable land, 181 thousand ha (9.6\%) permanent crops, and 57 thousand ha (3\%) pasture.

The energy-food linkage is the energy required for agriculture production; including fertilizer production, tillage, planting, weeding, pumping irrigation water, harvesting, transport, distribution, and storage as well as the energy used for inputs to these sectors (ADB, 2013; Chang et al., 2016). Renewable forms of energy, in the form of biofuels, have become a major agricultural output in some countries; resulting in competition for land used for food production or energy production (Yillia, 2016). As noted earlier in the proportion of national electricity generation from different technologies, biofuel was not a significant national contributor and biofuel crops production was practically non-existent in East Asia in 2005. Direct energy consumption for agriculture production was relatively low in all East Asian countries. 
Energy consumption for agriculture production was 1.7 million TJ (3\% of national energy consumption) in China, 251 thousand TJ (1\%) in Japan, and 146 thousand TJ (2\%) in South Korea.

In terms of environmental pressures, agriculture production was the largest consumer of direct scarce water for all three countries: 112.6 billion $\mathrm{m}^{3}$ (80\% of national scarce water consumption) in China, 7.9 billion $\mathrm{m}^{3}$ (50\%) in Japan, and 420 million $\mathrm{m}^{3}$ (40\%) in South Korea. Electricity generation was the second largest consumer of direct scarce water for Japan and the third largest for South Korea and China. Agriculture production was the largest emitter of direct GHG for all three East Asian countries. GHG emissions from agriculture production totaled 1 billion tons ( $\mathrm{t}$ ) (54\% of national GHG emissions) in China, 1 billion t (54\%) in Japan, and 36.3 million t (52\%) in South Korea. Agriculture production was similarly the largest $\mathrm{SO}_{\mathrm{x}}$ emitter totaling 15.1 million $\mathrm{t}$ (51\% of national $\mathrm{SO}_{\mathrm{x}}$ emissions) in China. In contrast, electricity generation in Japan and South Korea was responsible for the largest direct $\mathrm{SO}_{\mathrm{x}}$ emissions totaling, respectively, 789 thousand $\mathrm{t}(44 \%)$ and 601 thousand t (42\%).

\subsection{Direct and Indirect (Virtual Flows) Water-Energy-Food and Environmental Inter-Linkages}

\subsubsection{National Footprints}

Table 1 presents total direct and indirect (i.e. virtual flows) water-energy-food and environmental pressures by final household consumption. For example, Table 1 illustrates that the Secondary and Tertiary Sectors in China were responsible for consumption of, respectively, 80.2 million ha (19\%) and 140 million ha (34\%) of the national agriculture land footprint. Japan’s Secondary and Tertiary Sectors, respectively, accounted for 8.6 million ha (56\%) and 4.8 million ha (31\%) of the national agriculture land footprint. South Korea’s Secondary and Tertiary Sectors, respectively, accounted for 2.7 million ha (51\%) and 1.6 million ha (31\%) of the national agriculture land footprint. In other words, virtual flows of agricultural commodities and the environmental pressures associated with the consumption of the commodities are accounted for per sector and region of final household consumption. Accounting for the hidden interregional virtual trade flows and footprints of each East Asian country provides a unique perspective of the WEFN analysis. The largest consumer of water in China totaling 88.6 billion $\mathrm{m}^{3}$ (37\% of national water footprint) was for the production of household consumption of agricultural products. In contrast, Japan's and South Korea's household consumption for industrial products were the largest consumers of water 
totaling, respectively, 38 billion $\mathrm{m}^{3}$ (38\%) and 2.2 billion $\mathrm{m}^{3}$ (37\%). The energy footprint of the consumption of agricultural products was relatively low in all three East Asian countries totaling: China 1.8 million TJ (5\% of national energy footprint), Japan 173 thousand TJ (1\%), and South Korea 98 thousand TJ (2\%). In terms of environmental pressures, China's consumption of primary products caused the largest impact on scarce water totaling 44.7 billion $\mathrm{m}^{3}$ (39\% of national scarce water footprint). Japan's and South Korea's consumption of industrial products caused the largest amount of scarce water consumption along the supply chain totaling, respectively, 7.8 billion $\mathrm{m}^{3}$ (38\%) and 928 million $\mathrm{m}^{3}$ (46\%). The GHG $\left(\mathrm{CO}_{2}\right.$, $\mathrm{CH}_{4}$, and $\mathrm{N}_{2} \mathrm{O}$ ) and $\mathrm{SO}_{x}$ emissions footprints were largest for the consumption of services for all East Asian country.

Table 1 National Water-Energy-Food and Environmental Pressures Footprints

\begin{tabular}{|c|c|c|c|c|c|c|c|c|c|c|c|c|c|c|c|c|c|c|}
\hline \multirow[b]{2}{*}{$\begin{array}{r}\text { Resource: } \\
\text { unit: }\end{array}$} & \multicolumn{6}{|c|}{ People's Republic of China } & \multicolumn{6}{|c|}{ Japan } & \multicolumn{6}{|c|}{ Republic of Korea } \\
\hline & $\begin{array}{c}\text { Total } \\
\text { Water } \\
\text { (million } \\
\text { m3) }\end{array}$ & $\begin{array}{c}\text { Scarce } \\
\text { Water } \\
\text { (million } \\
\text { m3) }\end{array}$ & $\begin{array}{l}\text { Energy } \\
\text { (terajoule) }\end{array}$ & $\begin{array}{l}\text { Land } \\
(1,000 \\
\text { hectare })\end{array}$ & $\begin{array}{l}\text { GHG } \\
\text { (CO2 e } 1,000 \\
\text { ton) }\end{array}$ & $\begin{array}{c}\text { SOx } \\
(1,000 \\
\text { ton })\end{array}$ & $\begin{array}{c}\text { Total } \\
\text { Water } \\
\text { (million } \\
\text { m3) }\end{array}$ & $\begin{array}{c}\text { Scarce } \\
\text { Water } \\
\text { (million } \\
\text { m3) }\end{array}$ & $\begin{array}{l}\text { Energy } \\
\text { (terajoule) }\end{array}$ & $\begin{array}{l}\text { Land } \\
(1,000 \\
\text { hectare })\end{array}$ & $\begin{array}{l}\text { GHG } \\
\text { (CO2 } \mathrm{e} 1,000 \\
\text { ton) }\end{array}$ & $\begin{array}{c}\text { SOX } \\
(1,000 \\
\text { ton) }\end{array}$ & \begin{tabular}{|c} 
Total \\
Water \\
(million \\
m3)
\end{tabular} & $\begin{array}{c}\text { Scarce } \\
\text { Water } \\
\text { (million } \\
\text { m3) }\end{array}$ & $\begin{array}{l}\text { Energy } \\
\text { (terajoule) }\end{array}$ & $\begin{array}{l}\text { Land } \\
(1,000 \\
\text { hectare })\end{array}$ & $\begin{array}{c}\text { GHG } \\
\text { (cO2 e } \\
1,000 \text { ton) }\end{array}$ & $\begin{array}{l}\text { SOx } \\
(1,000 \\
\text { ton) }\end{array}$ \\
\hline \multirow[t]{2}{*}{ Primary Sectors } & 88,644 & 44,715 & $1,777,938$ & 197,288 & 545,702 & 5,957 & 19,171 & 3,056 & 172,838 & 2,064 & 21,107 & 27 & 742 & 213 & 98,034 & 943 & 14,176 & 171 \\
\hline & $37 \%$ & $39 \%$ & $5 \%$ & $47 \%$ & $12 \%$ & $27 \%$ & $19 \%$ & $16 \%$ & $1 \%$ & $13 \%$ & $2 \%$ & $1 \%$ & $12 \%$ & $10 \%$ & $2 \%$ & $18 \%$ & $4 \%$ & $13 \%$ \\
\hline \multirow[t]{2}{*}{ Secondary Sectors } & 44,096 & 21,287 & $13,379,503$ & 80,240 & $1,469,185$ & 6,212 & 38,040 & 7,796 & $7,678,311$ & 8,590 & 469,268 & 1,153 & 2,222 & 928 & $2,432,232$ & 2,711 & 158,933 & 570 \\
\hline & $19 \%$ & $19 \%$ & $38 \%$ & $19 \%$ & $33 \%$ & $29 \%$ & $38 \%$ & $40 \%$ & $42 \%$ & $56 \%$ & $42 \%$ & $48 \%$ & $37 \%$ & $46 \%$ & $43 \%$ & $51 \%$ & $40 \%$ & $43 \%$ \\
\hline \multirow[t]{2}{*}{ Tertiary Sectors } & 77,485 & 38,405 & $20,293,137$ & 139,958 & $2,426,588$ & 9,621 & 27,841 & 5,552 & $10,231,486$ & 4,795 & 639,788 & 1,214 & 1,647 & 592 & $3,175,834$ & 1,625 & 227,320 & 593 \\
\hline & $33 \%$ & $33 \%$ & $57 \%$ & $34 \%$ & $55 \%$ & $44 \%$ & $28 \%$ & $29 \%$ & $57 \%$ & $31 \%$ & $57 \%$ & $51 \%$ & $27 \%$ & $29 \%$ & $56 \%$ & $31 \%$ & $57 \%$ & $44 \%$ \\
\hline \multirow[t]{2}{*}{ Household water } & 26,387 & 10,494 & & & & & 15,880 & 2,850 & & & & & 1,446 & 304 & & & & \\
\hline & $11 \%$ & $9 \%$ & & & & & $16 \%$ & $15 \%$ & & & & & $24 \%$ & $15 \%$ & & & & \\
\hline Total & 236,612 & 114,901 & $35,450,578$ & 417,486 & $4,441,475$ & 21,790 & 100,933 & 19,254 & $18,082,635$ & 15,450 & $1,130,163$ & 2,394 & 6,057 & 2,037 & $5,706,100$ & 5,279 & 400,429 & 1,333 \\
\hline
\end{tabular}

\subsubsection{Regional Footprints}

Figure 2 illustrates the top ten regions with the largest water-energy-food and environmental pressures footprints in East Asia. All seven of China's regions are in the top ten. Central is the largest water-energyfood consumer and environmental pressure generator. In terms of East Asia's (i.e. China, Japan, and South Korea) regional footprints, China’s Central region consumption represented 59.4 billion $\mathrm{m}^{3}(17 \%)$ of total water, 23.6 billion $\mathrm{m}^{3}$ (17\%) of scarce water, 8.5 million TJ (14\%) of energy, and 115 million ha (26\%) of agriculture land and emitted 1.1 billion t (18\%) of GHG and 5.7 million t (22.2\%) of $\mathrm{SO}_{\mathrm{x}}$. 
Figure 2 Top Ten Region Water-Energy-Food and Environmental Pressures Footprints

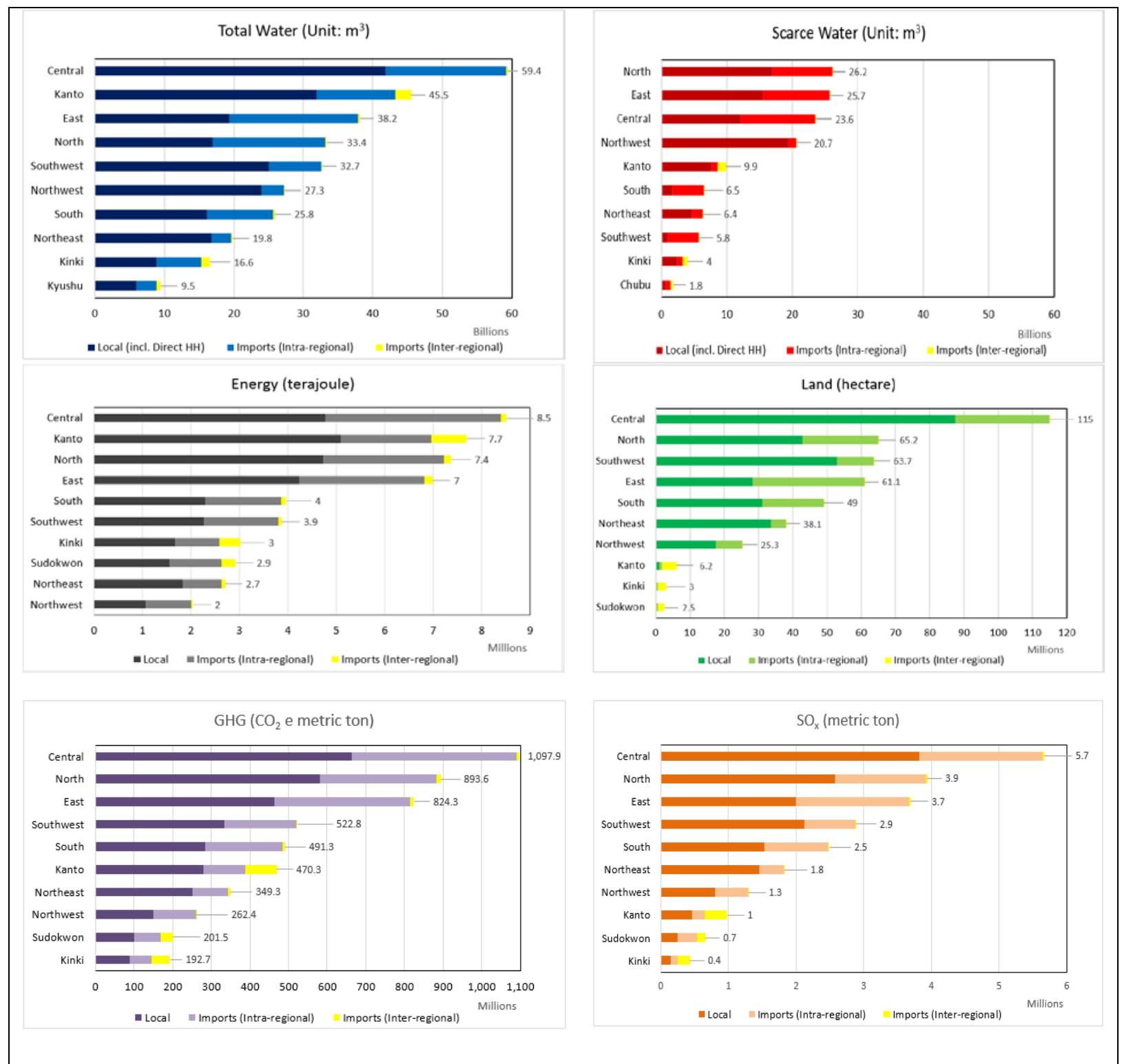

The water footprint and scarce water footprint include, respectively, direct household water and household scarce water consumption. The region footprint is equal to local consumption (darker color) + imported intra-regional virtual flows (lighter color) + imported (yellow) inter-regional virtual flows.

In terms of water stress and energy, as a very water stressed country China would be the most adversely affected. In East Asia, the largest consuming regions of direct and indirect scarce water inputs for electricity consumption were China's very water stressed East (3.8 billion $\mathrm{m}^{3}$ ), slightly water stressed Central (1.5 billion $\left.\mathrm{m}^{3}\right)$, and extremely water stressed North $\left(1\right.$ billion $\left.\mathrm{m}^{3}\right)$ and Japan’s slightly water stressed Kanto (1.8 
billion $\mathrm{m}^{3}$ ). The water-food linkage was dominated by China's regions. The top four water consuming regions for the production of agriculture products were Northwest (56.3 billion $\mathrm{m}^{3}$ ), Central (53.5 billion $\mathrm{m}^{3}$ ), East (33.2 billion $\mathrm{m}^{3}$ ), and Southwest (25.2 billion $\mathrm{m}^{3}$ ). The largest scarce water consuming regions for agricultural products were China's very water stressed Northwest (45.5 billion $\mathrm{m}^{3}$ ), North (28 billion $\mathrm{m}^{3}$ ), East (24.7 billion $\mathrm{m}^{3}$ ), and Central (17.9 billion $\mathrm{m}^{3}$ ). The energy-food linkage demonstrates that the top four largest direct and indirect energy consumers for agricultural consumption were China's Central (631.5 thousand TJ), North (386.2 thousand TJ), East (357.2 thousand TJ), and Southwest (354.9 thousand TJ). Regionally, direct and indirect GHG and $\mathrm{SO}_{\mathrm{x}}$ emissions were dominated by China's regions. The North and Central contributed, respectively, 266.7 million t and 245.4 million t of GHG emissions from other services consumption. The Central and Southwest regions contributed, respectively, 1.7 million t and 1.1 million t of $\mathrm{SO}_{\mathrm{x}}$ emissions from agriculture consumption.

\subsubsection{Final Household Consumption of Commodities}

The panel charts in Figure 2 present the three top final household consumption of commodities in East Asia responsible for the largest energy-water-food and environmental pressure footprints. As noted in the section above, China's supply chain for agricultural products was the largest consumers of water and agriculture land footprints, followed by the construction sector with 42.6 million $\mathrm{m}^{3}$ of water (18\%), 80.2 million ha displaced agriculture land (19\%), and 8.9 million TJ (25\%) of energy. China's construction industries were also the second largest consumer of 20.8 million $\mathrm{m}^{3}(18 \%)$ of scarce water and contributed 1 billion t (24\%) GHG and 4.7 million t (21\%) of $\mathrm{SO}_{\mathrm{x}}$ emissions. South Korea’s and Japan's daily products (in Secondary Sectors) and other services (in Tertiary Sectors) were the top water-energy-food and scarce water consumers and the main contributor to GHG and $\mathrm{SO}_{\mathrm{x}}$ emissions. Supply chains for other services in Japan and South Korea were responsible for consumption of, respectively, 18.6 billion $\mathrm{m}^{3}$ (18\%) and 993 million $\mathrm{m}^{3}$ (16\%) of water footprints, 3.4 million ha (22\%) and 1 million ha (19\%) of displaced agriculture land footprints, and 5.5 million TJ (30\%) and 1.8 million TJ (32\%) of energy footprints. Other services in both countries generated large environmental pressures responsible for 3.8 billion $\mathrm{m}^{3}$ (20\%) and 353 million $\mathrm{m}^{3}$ (17\%) consumption of scarce water footprints and contributed 333.1 million t (29\%) and 127.9 million (32\%) to the GHG footprints and 595 thousand t (25\%) and 376 thousand $t(28 \%)$ to the $\mathrm{SO}_{\mathrm{x}}$ footprints. 
Unlike China, agriculture products in Japan and South Korea was the second largest consumer of, respectively, 19.2 billion $\mathrm{m}^{3}$ (19\%) and 742 million $\mathrm{m}^{3}$ (12\%) of national water footprint and third largest consumer of 2.1 million ha (13\%) and 943 thousand ha (18\%) of national displaced agriculture land footprint. South Korea's agricultural commodities imports from China and Japan, respectively, constituted a significant proportion of its consumption footprints: 135.3 million $\mathrm{m}^{3}$ and 29.4 million $\mathrm{m}^{3}$ (or, combined, 22.2\%) water footprint and 299.4 thousand ha and 1.8 thousand ha (or, combined, 32\%) displaced agriculture land footprint of agriculture commodities consumption.

\subsubsection{Per Capita Final Household Consumption}

Table 2 provides the breakdown of per capita total water, scarce water, energy, and land consumption and GHG and $\mathrm{SO}_{\mathrm{x}}$ emissions by East Asian region. Table 2 illustrates that China's per capita consumption of water-energy-food and GHG and $\mathrm{SO}_{\mathrm{x}}$ gases emissions are relatively low in comparison to per capita consumption in Japan and South Korea. With the exception of land and scarce water, Japan's and South Korea's per capita consumption of energy and generation of GHG gases was several multiples greater than China's per capita consumption. Japan's per capita consumption of water was several multiples greater than both China’s and South Korea’s per capita consumption.

Table 2 Per Capita Consumption by Region

\begin{tabular}{|c|c|c|c|c|c|c|c|}
\hline & Region & $\begin{array}{c}\text { Total Water } \\
\text { m3/capita }\end{array}$ & $\begin{array}{c}\text { Scarce Water } \\
\text { m3/capita }\end{array}$ & $\begin{array}{l}\text { Energy } \\
\text { TJ/capita }\end{array}$ & $\begin{array}{c}\text { Land } \\
\text { ha/capita }\end{array}$ & $\begin{array}{c}\text { GHG Emission } \\
\mathrm{CO}_{2} \text { e metric } \\
\text { ton/capita }\end{array}$ & $\begin{array}{l}\mathrm{SO}_{\mathrm{x}} \text { Emission } \\
\text { metric ton/capita }\end{array}$ \\
\hline \multirow{7}{*}{ China } & Northeast & 184 & 59 & 0.03 & 0.35 & 3.25 & 0.02 \\
\hline & North & 179 & 140 & 0.04 & 0.35 & 4.78 & 0.02 \\
\hline & East & 270 & 182 & 0.05 & 0.43 & 5.82 & 0.03 \\
\hline & South & 191 & 48 & 0.03 & 0.36 & 3.62 & 0.02 \\
\hline & Central & 169 & 67 & 0.02 & 0.33 & 3.12 & 0.02 \\
\hline & Northwest & 230 & 175 & 0.02 & 0.21 & 2.21 & 0.01 \\
\hline & Southwest & 136 & 24 & 0.02 & 0.26 & 2.17 & 0.01 \\
\hline \multirow{9}{*}{ Japan } & Hokkaido & 924 & 80 & 0.14 & 0.14 & 9.15 & 0.02 \\
\hline & Tohoku & 622 & 65 & 0.12 & 0.07 & 7.35 & 0.01 \\
\hline & Kanto & 897 & 195 & 0.15 & 0.12 & 9.26 & 0.02 \\
\hline & Chubu & 666 & 134 & 0.13 & 0.14 & 8.68 & 0.02 \\
\hline & Kinki & 763 & 183 & 0.14 & 0.14 & 8.87 & 0.02 \\
\hline & Chugoku & 677 & 92 & 0.14 & 0.09 & 8.68 & 0.02 \\
\hline & Shikoku & 702 & 117 & 0.13 & 0.10 & 8.47 & 0.02 \\
\hline & Kyushu & 710 & 88 & 0.13 & 0.12 & 8.58 & 0.02 \\
\hline & Okinawa & 785 & 86 & 0.17 & 0.11 & 8.65 & 0.02 \\
\hline \multirow{4}{*}{ S. Korea } & Sudokwon & 99 & 39 & 0.13 & 0.11 & 8.85 & 0.03 \\
\hline & Jungbukwon & 194 & 55 & 0.12 & 0.11 & 8.77 & 0.03 \\
\hline & Yeongnamkwon & 134 & 40 & 0.11 & 0.12 & 7.96 & 0.03 \\
\hline & Honamkwon & 162 & 52 & 0.11 & 0.11 & 7.73 & 0.03 \\
\hline
\end{tabular}


Figure 3 Top Three Water-Energy-Food Footprints and Environmental Pressures by Final Consumption Sector

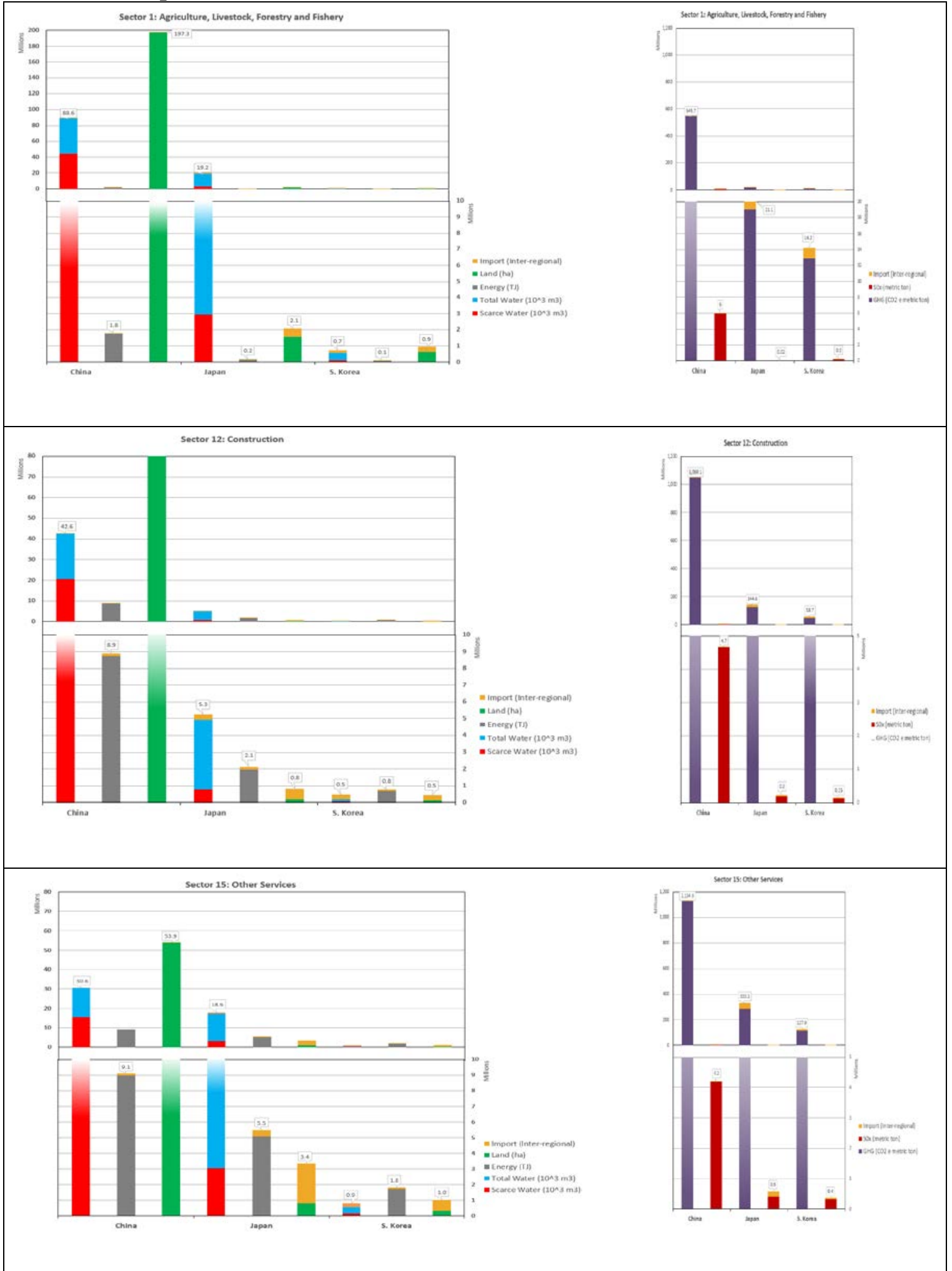

Note: The footprint is equal to local consumption + intra-regional +imported virtual flows. The panel charts highlight (yellow) virtual imports merely for illustrative purposes; i.e. virtual imports are not separate from the footprint. 


\subsection{Virtual Trade Flows Water-Energy-Food and Environmental Pressures}

\subsubsection{Regional Net Virtual Trade Flows}

Figure 4 presents the net virtual trade flow (net flow = export - import) of the top five net exporting and top five net importing regions of virtual water-energy-food and environmental pressures flows between regions. With the exception of the Southwest's scarce water (6 million $\mathrm{m}^{3}$ net import), China's seven regions were all net virtual exporters of water-energy-food and burdened with the associated environmental pressures of production and trade. Figure 4 Top Five Net Exporting Regions shows that the Northeast (1.5 billion $\mathrm{m}^{3}$ total water), North (1.3 billion $\mathrm{m}^{3}$ scarce water and 4 million ha land), and East (563 thousand TJ energy, 61.3 million t GHG, and 2.1 million t $\mathrm{SO}_{\mathrm{x}}$ ) were the largest net virtual exporters in East Asia. China’s Northeast and North are significant agricultural and industrial production regions and the East region possesses a high concentration of industries and energy generation capacity. Figure 4 Top Five Net

\section{Figure 4 Top Five Net Import/Export Virtual Water-Energy-Land and Environmental Pressures Regions}

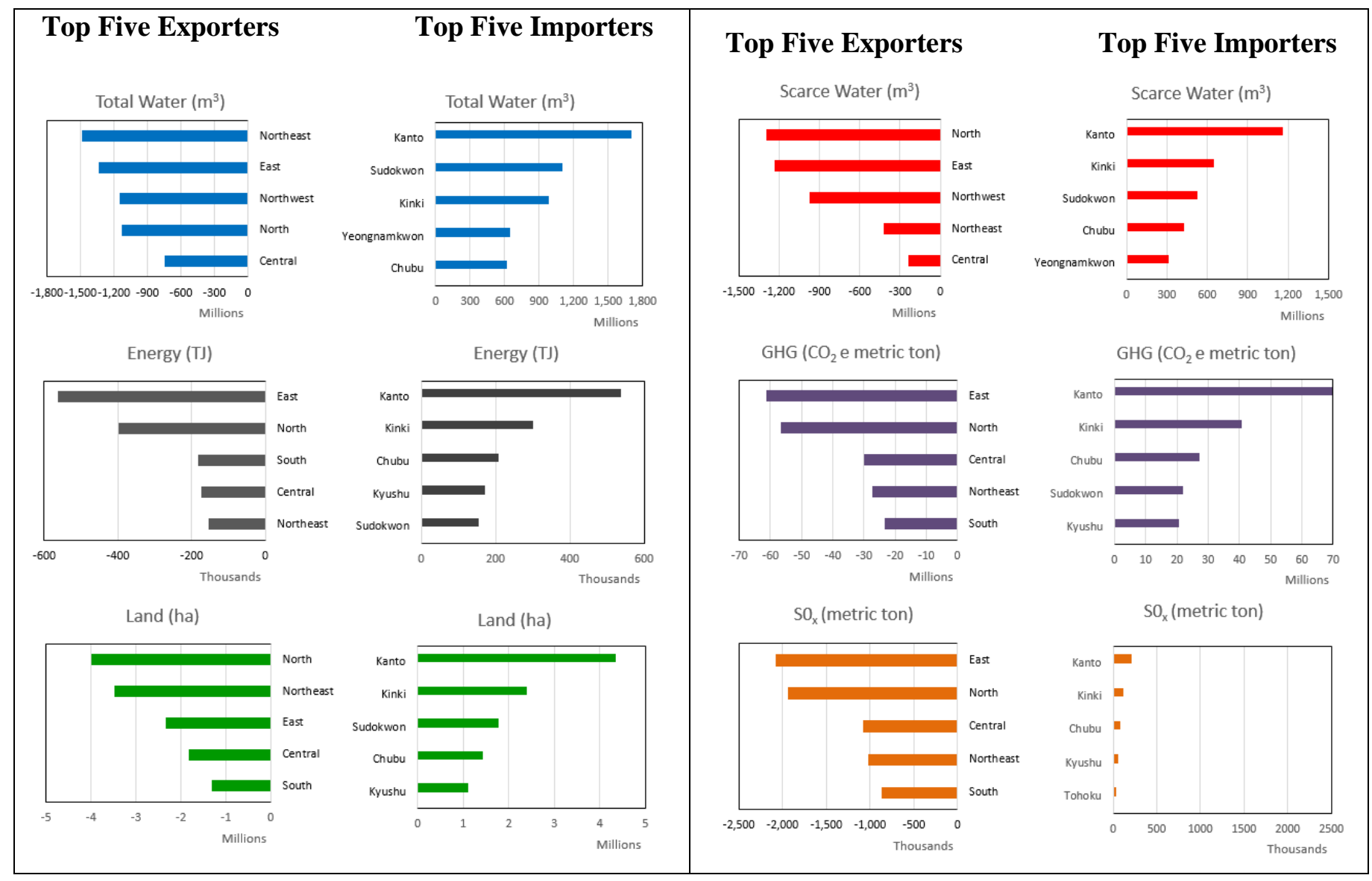


Importing Regions shows that Japan's Kanto is the largest net importer of 1.7 billion $\mathrm{m}^{3}$ total water, 1.2 billion $\mathrm{m}^{3}$ scarce water, 539 thousand TJ energy, and 4.4 million ha agriculture land and outsourcing 69.7 million t GHG and 207.3 thousand $\mathrm{SO}_{\mathrm{x}}$. With the exception of Okinawa's scarce water (152 million $\mathrm{m}^{3}$ net export), Japan's nine regions were all net virtual importers of water-energy-food and generated environmental pressures in other East Asian regions. With the exception of Yeongnamkwon's and Honamkwon's energy (44.7 thousand TJ and 23.5 thousand TJ) net export, South Korea's four regions were all net virtual importers of water-energy-food and generated GHG emissions in other regions. All four of South Korea's regions were net exporters of $\mathrm{SO}_{\mathrm{x}}$ emissions.

\subsubsection{Net Intra-regional and Inter-regional Virtual Water-Energy-Food and Environmental Pressures Export Flows}

Figure 5a-f provides greater insight into the origins and pattern of intra-regional (i.e. within national boundaries) and transnational inter-regional (i.e. outside of national boundaries) virtual export flows of water-energy-food and environmental pressures (scarce water and GHG and $\mathrm{SO}_{\mathrm{x}}$ emissions) by region in East Asia. Figure 5a-b ranks the degree of water scarcity for all regions in China, Japan, and South Korea in terms of the Water Stress Index (WSI) (see Pfister et al., 2009). A WSI of 0.5 is the threshold between moderate and severe water stress. According to Figure 5a-b, Japan's regions range from water abundant to slightly water stressed, China's regions range from water abundant to extremely water stressed, and South Korea's regions are only slightly water stressed (Sudokwon is moderately water stressed). In terms of intraregional virtual water flows: China's highly water stressed Northwest was a significant provider of both total water and scarce water to the extremely water stressed North, water stressed East, slightly water stressed Central, and water abundant Southwest and South; Japan's slightly water stressed Kanto was a recipient of virtual water from water abundant Hokkaido and Tohoku; and, moderately water stressed Sudokwon received virtual water from the slightly water stressed other three South Korean regions. In terms of transnational inter-regional virtual water flows, the top ten virtual flows all originated from China's slightly water stressed Northeast and very water stressed East and Northwest to Japan's slightly water stressed Kanto and Kinki and South Korea’s moderately water stressed Sudokwon. 
Figure 5c-f illustrates the intra-regional and transnational inter-regional virtual flows for energy and land and the offloading of GHG and $\mathrm{SO}_{\mathrm{x}}$ air pollutants. Figure 5c-f indicates regions which were net virtual exporters (dark blue) and net virtual importers (light blue). In terms of intra-regional virtual flows, China’s Northeast, Northwest, and Central regions were burdened with environmental pressures and were significant exporters of virtual energy and land to the North and East regions. Similarly, Japan's Kanto and South Korea's Sudokwon regions were net virtual importers of intra-regional energy and land and were responsible for offloading environmental pressures. Transnational inter-regional virtual flows of energy and land demonstrate that China was a net virtual exporter to Japan and South Korea. China's North and East regions constitute seven of the top ten virtual energy export flows. Major recipients of China's virtual energy flows were Japan's Kanto, Kinki, and Chubu. China’s Northeast, North, and East regions were virtual land exporters to Japan's Kanto and Kinki and South Korea’s Sudokwon. Similarly, China bore the burden of environmental degradation from transnational inter-regional trade and the export of commodities to Japan and South Korea. China's regions incurred the largest amount of virtual GHG and $\mathrm{SO}_{\mathrm{x}}$ emissions in the North and East embodied in its trade of products and services to Japan and South Korea. Japan's Kanto and Kinki and South Korea's Sudokwon regions were the major beneficiaries of this virtual environmental offloading. 
Figure 5 East Asia Virtual Water-Energy-Food and Environmental Pressure (Scarce Water, $\mathrm{CO}_{2}$, and non- $\mathrm{CO}_{2}$ ) Flows by Region

a. Net Virtual Water Flows and Water Scarcity by Region (Unit: million cubic meter $\left(10^{6} \mathrm{~m}^{3}\right)$ )

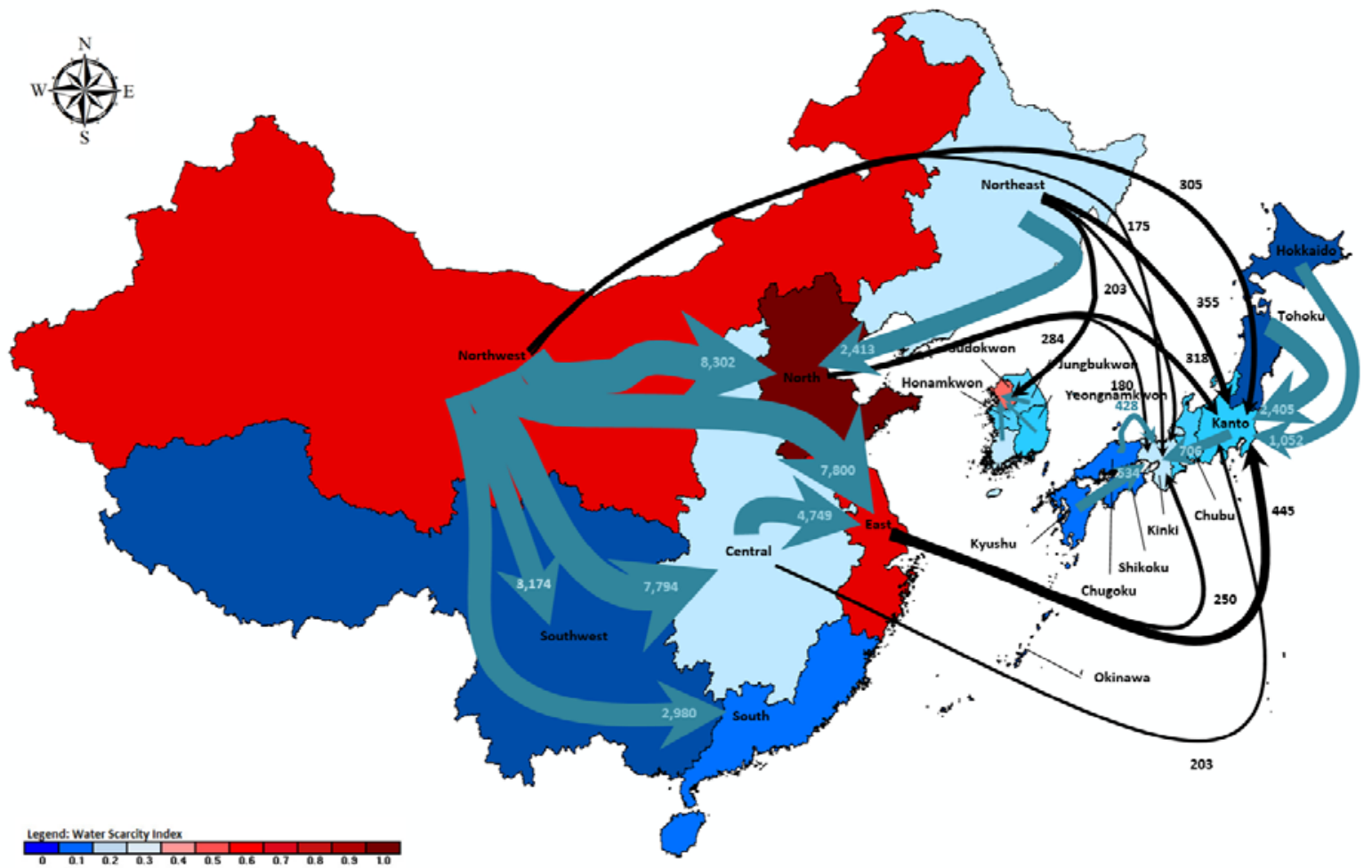

b. Net Virtual Scarce Water Flows and Water Scarcity by Region (Unit: million cubic meter $\left(10^{6} \mathrm{~m}^{3}\right)$ )

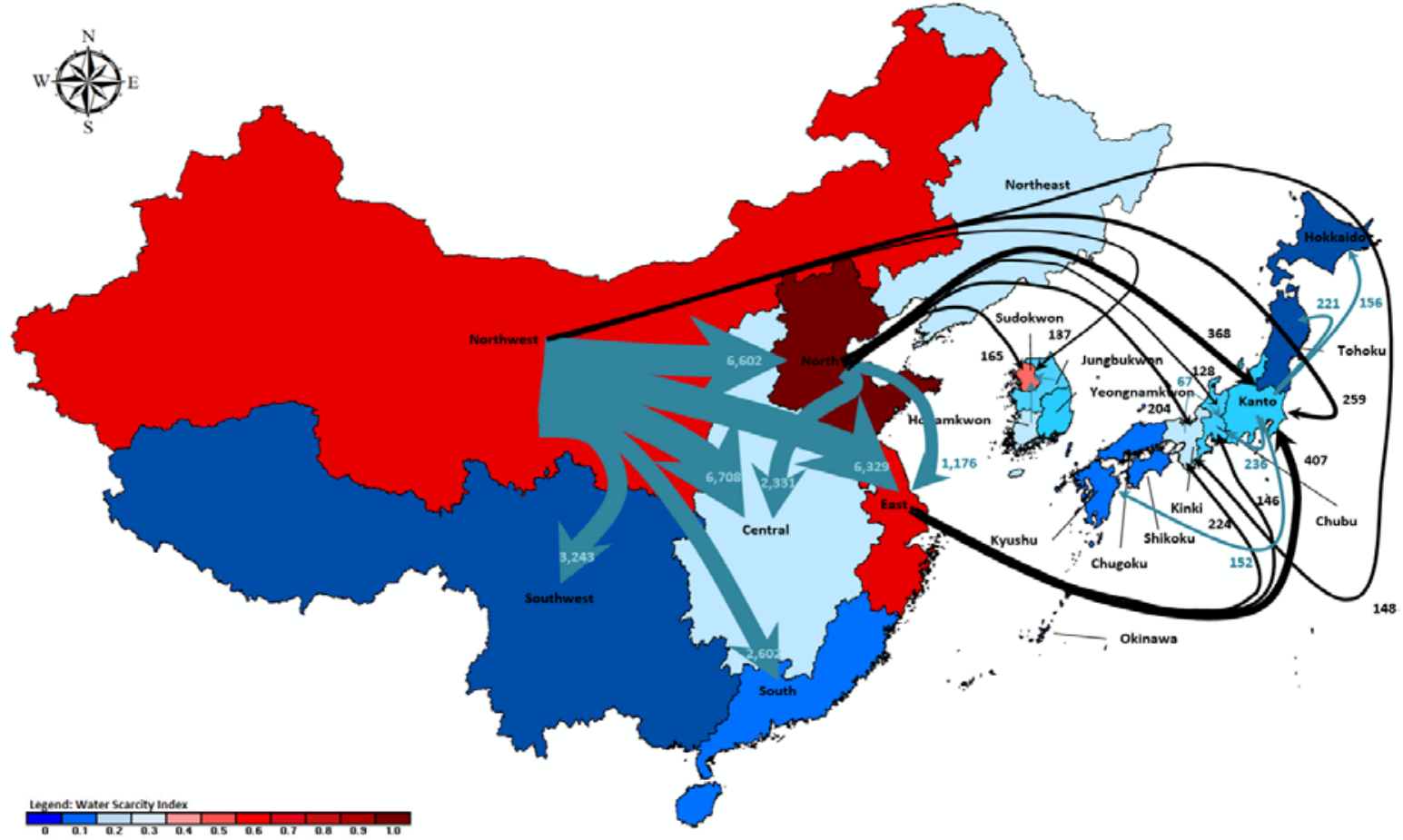

Arrows are proportionate to the size (unit: million cubic meters) of the net flows (net flows = export - import) of virtual water trade: top seven China intra-regional, top five Japan intra-regional, top three South Korea intra-regional, and the top ten transnational inter-regional export destinations by region in East Asia. Figure 6a-b illustrates the level of water abundance or water stress by region based on Pfister et al. (2009) Water Scarcity Index (WSI); dark blue indicates water abundance, light blue slight water stress, pink moderate water stress, red high water stress, and dark red severe water stress. 
c. Net Virtual Energy Flows (Unit: petajoule (10 ${ }^{15}$ joule))

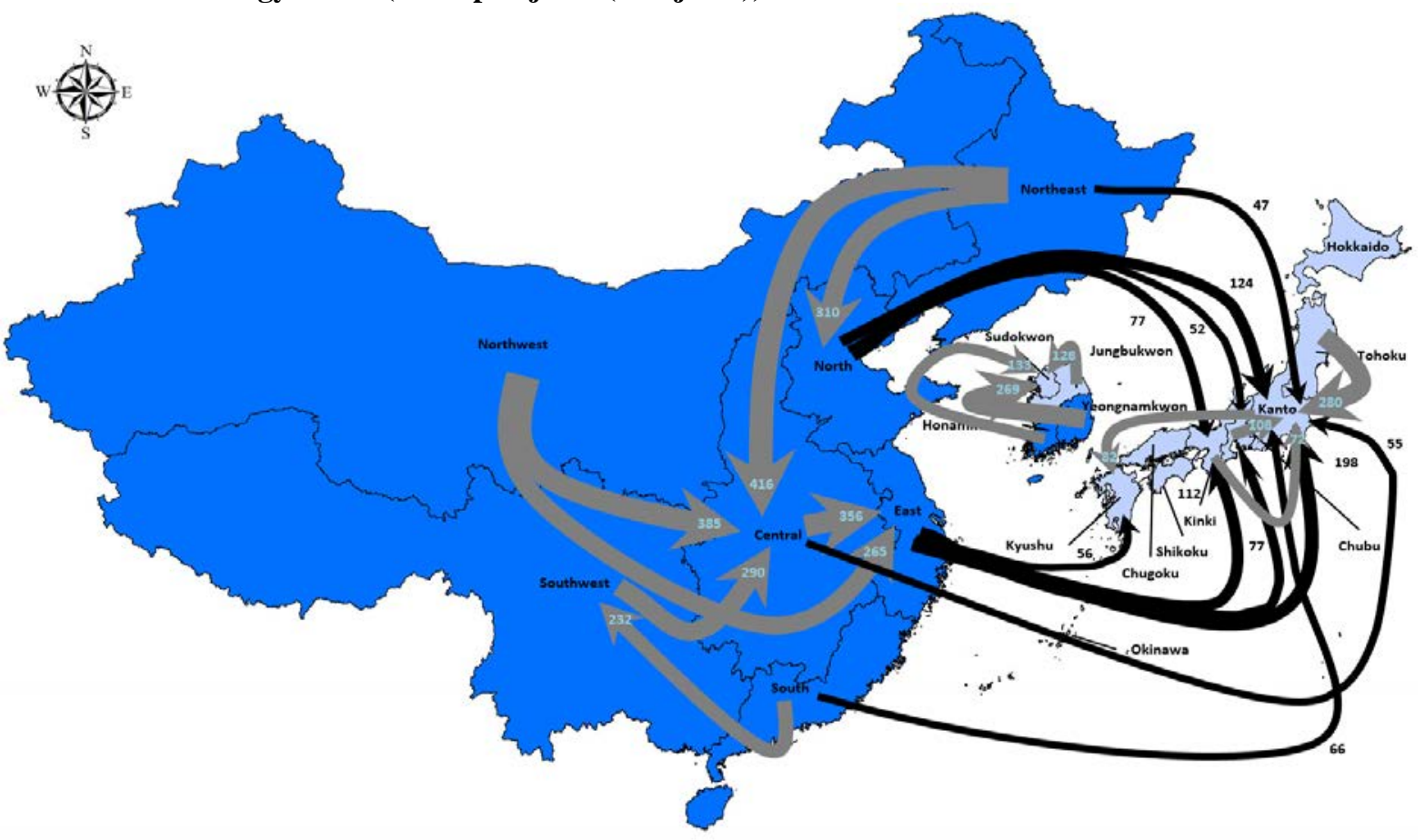

d. Net Virtual Agriculture Land Flows (Unit: thousand hectare $\left(10^{3}\right.$ ha))

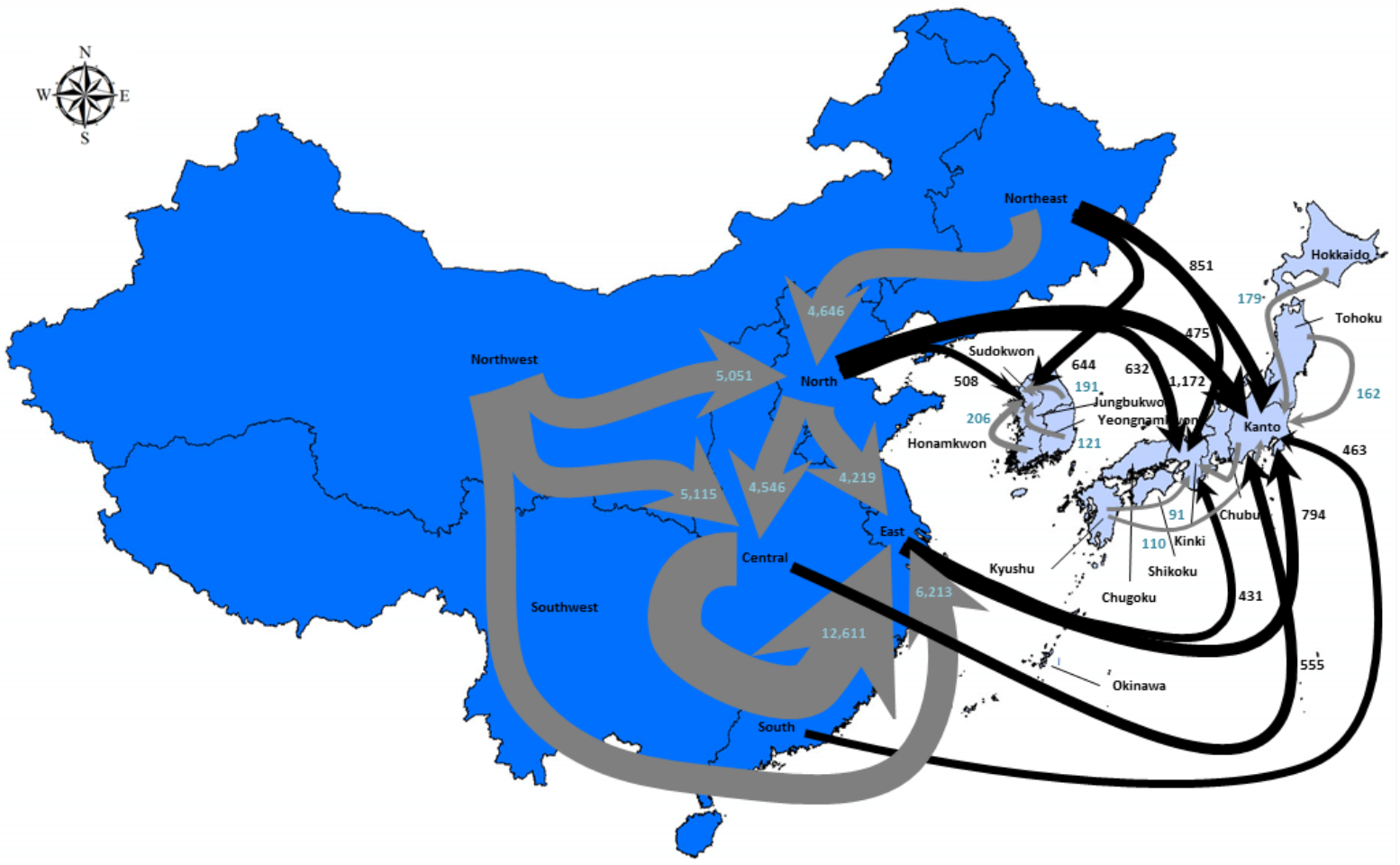


e. Net Virtual Green House Gases Flows (Unit: ten thousand metric ton $\left(10^{4} t\right)$ )

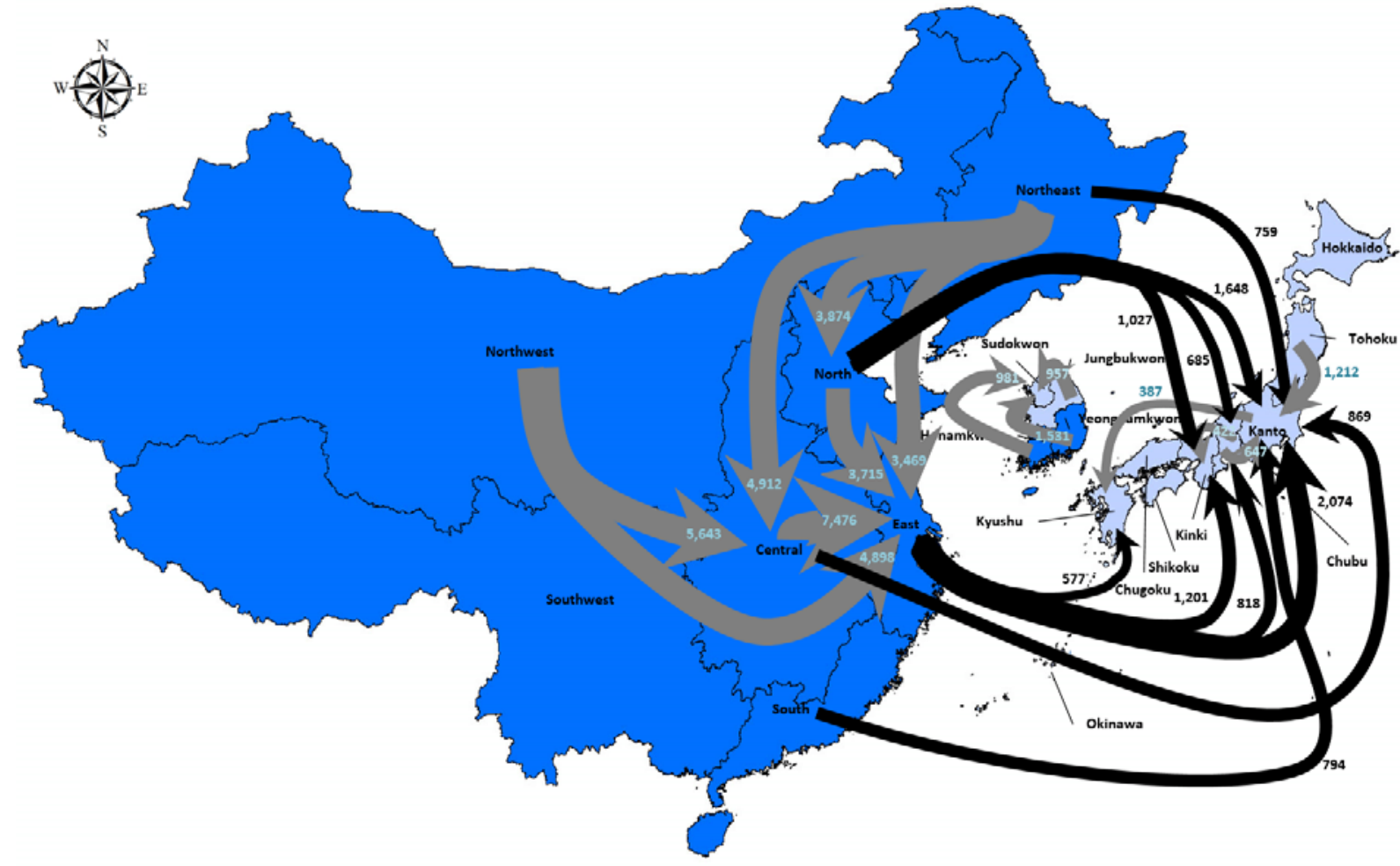

f. Net Virtual $\mathrm{SO}_{\mathrm{x}}$ Flows (Unit: ten thousand metric ton $\left(10^{4} \mathrm{t}\right)$ )

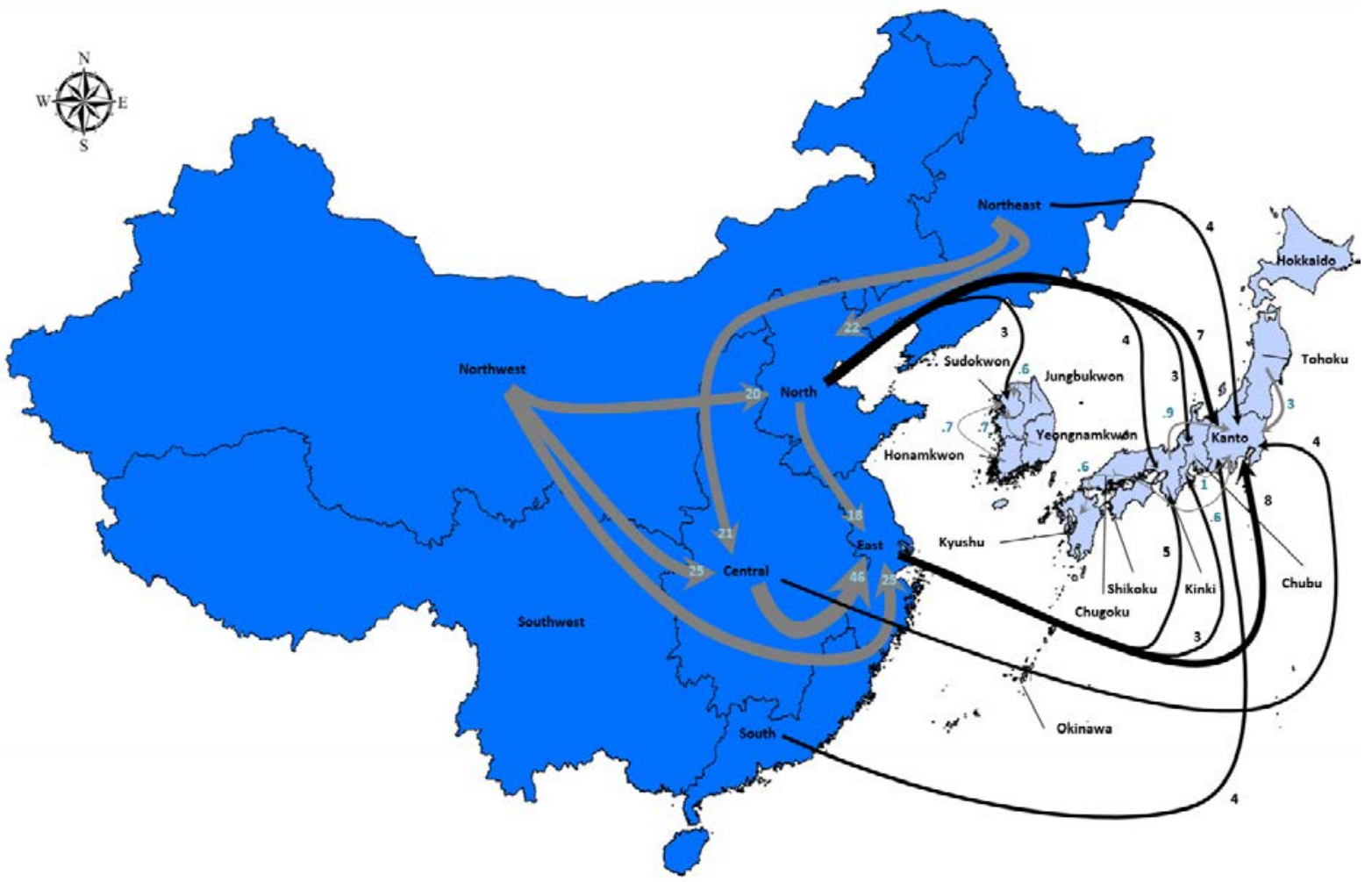

Arrows are proportionate to the size of the net flow (net flow = export - import) of virtual trade: top seven China intra-regional, top five Japan intra-regional, top three South Korea intra-regional, and the top ten transnational inter-regional export destinations by region in East Asia. In Figure 5c-f, dark blue indicates net virtual exporter and light blue net virtual importer region. Figure 5c-f shows both the largest intra-regional and transnational inter-regional net virtual flows embodied in trade: energy (unit: petajoule or one quadrillion joule), land (unit: thousand hectare), and GHG (unit: ten thousand metric ton) and $\mathrm{SO}_{x}$ (unit: ten thousand metric ton) air pollutants. 


\section{DISCUSSION/CONCLUSION}

Globalization increases the interconnectedness of people, places, and the consumption of water-energyfood. Trade connects consumption of resources, production, and the exchange of products and services while at the same time distances impacts on foreign ecosystems. In economic value, China possessed a considerable trade deficit with South Korea and a small trade surplus with Japan. However, the results of this paper show that China's current national export oriented economic growth strategy - in the context of the hidden virtual flows of water, energy, and food (agriculture land) and environmental pressures - is not sustainable. In terms of water-energy-food, China was a substantial virtual net water-energy-food exporter to both Japan and South Korea. Overall, via inter-regional trade, China bore the burden of environmental pressures associated with the production of exports for the benefit of both Japan and South Korea. Competing national priorities and global drivers have a strong influence on the water-energy-food resources that requires consideration of withdrawal, environmental degradation, and resource scarcity. The nexus approach is, therefore, crucial in identifying entry points in a defined economy to identify and manage tradeoffs between the three subsystems and across various spatial scales.

The WEFN analysis reveals national economic and environmental priorities of each country in the East Asia region. China’s significant water-energy-food investment and policy of maintaining 95\% selfsufficiency in grain production signifies the strategic importance of its agriculture sector. China's prioritization of economic growth and trade in low value added sectors 'wearing apparel and textile products', 'products for daily use', 'household electrical appliances', and 'manufactured products' consumes a significant quantity of water-energy-food within its territory to satisfy consumers' demands in Japan and South Korea. For example, Japan’s import from China accounted for 74\% water, 79\% energy, and $100 \%$ displaced agriculture land of household consumption for clothing and apparel commodities. Similarly, South Korea’s imports from China accounted for 82\% water, 36\% energy, and 98\% displaced agriculture land of household consumption for clothing and apparel commodities. China's national priorities surrounding water, energy, and food must necessarily balance between competing demands for national production and trade to support economic growth, maintain political stability, support livelihoods, and address increasing public awareness and concern over environmental quality (Liu and $\mathrm{Mu}, 2016$ ). 
However, increasing competing demands for limited resources has resulted in tension between agricultural self-sufficiency and the requirements for water and energy supply for the industrializing economy.

Trade can be an important mechanism for overcoming a country's resource bottlenecks of water, energy, and food. South Korea's and Japan's national priorities place the agriculture sector at a lower priority and emphasize the manufacturing and services sectors. Japan's and South Korea's post-industrial economies (i.e. services and trade-based) are relatively uncoupled from domestic resource constraints. National energy and food security are interwoven with trade and foreign policy; e.g., Japan and South Korea are the world's fourth and fifth largest importers of crude oil and second and seventh largest importers of natural gas (World Factbook, 2016). Via inter-regional trade with Japan and China, South Korea imported and consumed 2.4 billion $\mathrm{m}^{3}$ of virtual water embodied in products and services; significantly contributing to South Korea's total national water footprint of 6.1 billion $\mathrm{m}^{3}$. Trade is an important mechanism for overcoming resource bottlenecks, but regional specialization is not necessarily mutually beneficial. The production, consumption, and trade of virtual water, energy, and food have negative environmental implications. Japan and South Korea externalize environmental impacts by importing low value added and pollution intensive commodities produced in China. In 2005, Japan and South Korea externalized virtual environmental pressures totaling 4.4 billion $\mathrm{m}^{3}$ scarce water and 270.3 million t GHG and 1.1 million t $\mathrm{SO}_{\mathrm{x}}$ emissions by the consumption of China’s exported goods and services.

WEFN interactions take place within the context of global drivers, increasing population and economic growth, international and regional trade, demographic shifts and urbanization, and increasing per capita prosperity with corresponding changes in lifestyle patterns and dietary demands. These drivers impact demand for energy and food production and use of limited water resources. East Asia, particularly China, is increasingly an urban society placing greater stress on water, energy, and food needs (ADB, 2013). China possesses over $20 \%$ of the world's population, but less than $7 \%$ of global freshwater resources. China is one of the most water stressed countries in the world. Water consumption is surging in China, particularly in the urban and industrial sectors. Annually, almost half of China's 650 largest cities suffer from water shortage. China suffers an estimated 40 billion $\mathrm{m}^{3}$ annual water shortfall; urban water shortage of 5-6 billion $\mathrm{m}^{3}$ and irrigation shortfall of 35 billion $\mathrm{m}^{3}$ per year (Kahrl and Roland-Holst, 2008; Hofstedt, 2010). China 
is the world's largest energy consumer; as water availability is decreasing, water demand for electricity generation is increasing. China is the largest producer and consumer of agricultural products in the world. In 2005, China ranked number one in the production and consumption of paddy rice, cotton, wheat, coarse grains, corn, pork, chicken (broiler), walnuts, peaches and nectarines, plums, apricots, pears, grapes, and apples (USDA 2006a-c, 2008a-b, 2009). As the middle class grows in China, their dietary and lifestyle patterns change (e.g. increase in meat and luxury products consumption), consuming more water. China's annual per capita water requirement for food consumption increased from $255 \mathrm{~m}^{3}$ in 1961 to $860 \mathrm{~m}^{3}$ in 2003 (Chang et al., 2016). China's large urbanization (more than 100 cities have at least one million inhabitants) are also placing increased demands on water and electricity. The prioritization of water for energy generation or industrial use over water for agricultural irrigation is increasingly common (Cai, 2008; Biba, 2016). According to FAO, China's total water withdrawal in 2005 was an estimated $554.1 \mathrm{~km}^{3}$; comprised of $65 \%\left(358 \mathrm{~km}^{3}\right)$ for irrigation, 12\% $\left(67.5 \mathrm{~km}^{3}\right)$ for municipal use, and 23\% (128.6 km³) for industry. In comparison, China's total water withdrawal in 1993 was $525.5 \mathrm{~km}^{3}$; of which, $77 \%\left(407.7 \mathrm{~km}^{3}\right)$ was for irrigation, 5\% (25.2 km³) for municipal use, and 18\% (92.6 km³) for industrial use (AQUASTAT, 2016).

With the continuing growth of China's economy and level of urbanization, China will require more resources to meet its growing domestic consumption, let alone sustain its national export strategy. Incorporating water scarcity into water consumption analysis permits a better understanding of the sectors causing water scarcity, the geographical distribution of regions suffering from water scarcity, and the impact of trade flows on both water-abundant and water-scarce regions. China's substantial intra-regional virtual water flows from water scarce regions to other water scarce or water abundant regions does not mitigate the problem of local water shortage; it shifts the problem and increases the ecological inequality between China's regions. China's overall national level water problem remains the same. Beyond the limitation on the availability of freshwater for direct household consumption within regions, there may be restrictions from water scarcity on food production and energy development. Similarly, limited energy availability (or high energy costs) may constrain the ability to provide adequately clean water and sanitation services to population centers or produce food. These interlinkages make it increasingly crucial to account, quantify, and comprehend the cross-sectoral impacts and trade-offs in regional, national, and supra-national 
economies and economic priorities. A government's prioritization of economic growth and trade policies can result in water being diverted to industry and urban areas (over food production), and farm land appropriated for urban development. China’s major challenge will be efficiently managing and prioritizing its precious water-energy-land resources for domestic needs or export driven economic growth.

The application and quantification of an environmental WEFN is important to advance our understanding of resource management across scales. As this research illustrates, drivers of water-energyfood consumption can originate from beyond national and regional boundaries; as well as beyond natural ecosystem boundaries. Furthermore, there is a mismatch between regional resource availability and resource flows destinations, and the lack of consideration for environmental impact of trade policies. More often than not, resource scarce countries must make trade-offs decisions between pursuing national economic growth, diminishing environmental quality, food security, and trade policies. Trade can mitigate local scarcities, but it does so by externalizing resource extraction and pollution. With commodities and services being traded across economic and ecosystem boundaries, it is necessary for the management and governance of WEFN and the management of associated resources be driven to extend across scales as well. In the East Asia region, policy makers should integrate consideration of water, energy, and food resources into all aspects of planning and contribute to regional resilience. Building resilience into planning requires cooperation and coordinated decision making. Trade, regional integration, and domestic and foreign policy must comprehensively incorporate resilience, avoid sector and bureaucratic silos, and manage nexus trade-offs effectively. The results of this paper highlight the current WEFN and trade policy priorities of China, Japan, and South Korea in order to inform decisions to obtain sustainable solutions.

As far as the authors are aware, this study is the first tele-connected Water-Energy-Food Nexus (WEFN) analysis. The model is set apart from earlier WEFN approaches in that it quantifies the interlinkages between all three water-energy-food subsystems and associated environmental impacts at various scales - i.e. regional, national, and supra-national - using the harmonized TIIOT. The model is a practical tool for decision makers employing a country's or countries' nationally published economic, environmental, and socio-economic data. 


\section{ACKNOWLEDGEMENT}

Klaus Hubacek's Research was supported by the Czech Science Foundation under the project VEENEX (GA ČR no. 16-17978S)

\section{REFERENCES}

Abdelradi, F. and T. Serra (2015). Food-energy nexus in Europe: Price volatility approach. Energy Economics, Vol. 48: 157-67.

Aggarwal, V.K., M.G. Koo, S. Lee, and C. Moon (Eds.) (2008). Northeast Asia: Ripe for Integration? Springer-Verlag: Berlin Heidelberg.

al-Ansari, T., A. Korre, Z. Nie, and N. Shah (2015). Development of a life cycle assessment tool for the assessment of food production systems within the energy, water and food nexus. Sustainable Production and Consumption, Vol. 2: 52-66.

Allan, J. A. (1994). “Overall perspectives on countries and regions.” Water in Arab World: Perspectives and Progress. Harvard University Press, Cambridge, MA.

Antonelli, M. and S. Tamea (2015). Food-water security and virtual water trade in the Middle East and North Africa. International Journal of Water Resources Development, Vol. 31 (No. 3): 326-342

AQUASTAT (2016). The United Nations Food and Agriculture Organizations. Accessed on November 18, 2016 from: http://www.fao.org/nr/water/aquastat/countries_regions/chn/index.stm

Asian Development Bank (ADB) (2013). Thinking about Water Differently: Managing the Water-FoodEnergy Nexus. Mandaluyong City, Philippines: Asian Development Bank.

Asian Development Bank (ADB) (2014). Asian Development Outlook 2014 Update. Asia in Global Value Chains. Mandaluyong City, Philippines: Asian Development Bank.

Bachmann, C., M.J. Roorda and C. Kennedy (2015) Developing a multi-scale multi-region input-output model. Economic Systems Research 27, 172-193.

Bazilian, M., H. Rogner, M. Howells, S. Hermann, D. Arent, D. Gielen, P. Steduto, A. Mueller, P.

Komor, R.S.J. Tol, and K.K. Yumkella (2011). Considering the energy, water and food nexus: Towards an integrated modelling approach. Energy Policy, Vol. 39: 7896-7906.

Bazilian, M., R. Davis, P.T. Pienkos, and D. Arent (2013). The Energy-Water-Food Nexus through the lens of algal systems. Industrial Biotechnology, Vol. 9 (No. 4): 158-62.

Beijing Statistical Yearbook 2009. Beijing Municipal Bureau of Statistics, Survey Office of the National Bureau of Statistics in Beijing.

Berardy, A. and M.V. Chester (2017). Climate change vulnerability in the food, energy, and water nexus: Concerns for agricultural production in Arizona and its urban export supply. Environ. Res. Lett., Vol. 12: 1-14.

Biba, S. (2016). The goals and reality of the water-food-energy security nexus: the case of China and its southern neighbours. Third World Quarterly, Vol. 37 (No. 1): 51-70.

Brown, L.R. and B. Halweil (1998). China's water shortage could shake world food security. World Watch, Vol. 11 (No. 4): 10-21.

Cai, X. (2008). Water stress, water transfer and social equity in Northern China - Implications for policy reforms. Journal of Environmental Management, Vol. 87: 14-25.

Chang, Y., G. Li, Y. Yao, L. Zhang, and C. Yu (2016). Quantifying the Water-Energy-Food Nexus: Current status and trends. Energies, Vol. 9 (no. 65): 1-17.

Chiang, M. (2013). The potential of China-Japan-South Korea Free Trade Agreement. East Asia, Vol. 30: 199-216.

Cho, C. (2013). An exploration of reliable methods of estimating emergy requirements at the regional scale: Traditional emergy analysis, regional thermodynamic input-output analysis, or the conservation rule-implicit method. Ecological Modelling, Vol. 251: 288-296.

Dalin, C., N. Hanasaki, H. Qiu, D.L. Mauzerall, and I. Rodriguez-Iturbe (2014). Water resources transfers through Chinese interprovincial and foreign food trade. PNAS, Vol. 111 (no. 27): 9774-9779 
Daher, B.T. and R.H. Mohtar (2015). Water-energy-food (WEF) nexus tool 2.0: Guiding integrative resource planning and decision-making. Water International, Vol. 40 (No. 5-6): 748-71.

Daniels, P.L., M. Lenzen, and S.J. Kenway (2011). The ins and outs of water use - a review of multiregion input-output analysis and water footprints for regional sustainability analysis and policy.

Economic Systems Research Vol. 23 (No. 4): 353-370.

de Laurentiis, V., D.V.L. Hunt, and C.D.F. Rogers (2016). Overcoming food security challenges within an energy/water/food nexus (EWFN) approach. Sustainability, Vol. 8 (No. 95): 1-23.

Du, H., J. Guo, G. Mao, A.M. Smith, X. Wang, and Y. Wang (2011). CO2 emissions embodied in ChinaUS trade: Input-output analysis based on the emergy/dollar ratio. Energy Policy, Vol. 39: 5980-5987. European Communities (2001). Environmental Pressure Indicators for the EU. Luxembourg: Office for Official Publications of the European Communities. ISBN 92-894-0955-X.

Ewing, B.R., T.R. Hawkins, T.O. Wiedmann, A. Galli, A.E. Ercin, J. Weinzettel, and K. Steen-Olsen (2012). Integrating ecological and water footprint accounting in a multi-regional input-output framework. Ecological Indicators, Vol. 23:1-8.

Fang, K. R. Heijungs, and G.R. de Snoo (2014). Theoretical exploration for the combination of the ecological, energy, carbon, and water footprints: Overview of a footprint family. Ecological Indicators, Vol. 36: 508-518.

Feng, K., A. Chapagain, S. Suh, S. Pfister, and K. Hubacek (2011). Comparison of bottom-up and topdown approaches to calculating the water footprints of nations. Economic Systems Research, Vol. 23 (No. 4): 371-385.

Feng, K., S.J. Davis, L. Sun, X. Li, D. Guan, W. Liu, Z. Liu, and K. Hubacek (2013). Outsourcing CO2 within China. Proceedings of the National Academy of Sciences, Vol. 110: 11654-11659.

Feng, K., K. Hubacek, S. Pfister, Y. Yu, and L. Sun (2014a). Virtual scarce water in China.

Environmental Science \& Technology, Vol. 48 (No. 14): 7704-7713.

Feng, K., K. Hubacek, Y.L. Sui, and X. Li (2014b). The energy and water nexus in Chinese electricity production: A hybrid life cycle analysis. Renewable and Sustainable Energy Reviews, Vol. 39: 342-55.

Food and Agriculture (FAO) of the United Nations (2014). Walking the Nexus Talk: Assessing the Water-Energy-Food Nexus in the Context of the Sustainable Energy for All Initiative. FAO Water Reports No. 38. Food and Agriculture Organization of the Organization of the United Nations: Rome.

Fukui. "Plan on Conservation of Aquatic Environment in Fukui Prefecture.” Accessed on November 18, 2016 from: http://www.erc.pref.fukui.jp/sogo/d092/1998/92_0124.pdf

Gasiorek, M. and J. Lopez (2014). China-EU Global Value Chains: Who Creates Value, How and Where? Growing Linkages and Opportunities. Publications Office of the European Union: Luxembourg.

Gerbens-Leenes, P.W., A.Y. Hoekstra, and Th. Van der Meer (2009). The water footprint of energy from biomass: A quantitative assessment and consequences of an increasing share of bio-energy in energy supply. Ecological Economics, Vol. 68: 1052-60.

Gereffi, G. (2014). Global value chains in a post-Washington Consensus world. Review of International Political Economy, Vol. 21 (No. 1): 9-37

Gua, Y., Y. Dong, H. Wang, A. Keller, J. Xu, T. Chiramba, and F. Li (2016). Quantification of the water, energy and carbon footprints of wastewater treatment plants in China considering a water-energy nexus perspective. Ecological Indicators, Vol. 60: 402-409.

Hardy, L., A. Garrido, and L. Juana (2012). Evaluation of Spain's Water-Energy Nexus. International Journal of Water Resources Development, Vol. 28 (No. 1): 151-170

Hoekstra, A.Y. and P.Q. Hung (2005). Globalization of water resources: International virtual water flows in relation to crop trade. Global Environmental Change, Vol. 15 (No. 1): 45-56.

Hofstedt, T (2010). China's water scarcity and its implications for domestic and international stability. Asian Affairs: An American Review, Vol. 37 (No. 2): 71-83.

Holland, R.A., K.A. Scott, M. Florke, G. Brown, R.M. Ewers, E. Farmer, V. Kapos, A. Muggeridge, J.P.W. Scharlemann, G. Taylor, J. Barrett, and F. Eigenbrod (2015). Global impacts of energy demand on the freshwater resources of nations. PNAS, Vol. 112 (No. 48): 6707-6716.

Hubacek, K., D. Guan, J. Barrett, and T. Wiedmann (2009). Environmental implications of urbanization and lifestyle change in China: Ecological and water footprints. Journal of Cleaner Production, Vol. 17: 1241-48. 
Hubacek, K., K. Feng, J.C. Minx, S. Pfister, and N. Zhou (2014). Teleconnecting consumption to environmental impacts at multiple spatial scales: Research frontiers in environmental footprinting. Journal of Industrial Ecology, Vol. 18 (No. 1): 7-11.

Institute of Developing Economies, Japan External Trade Organization (IDE-JETRO). 'Transnational Interregional Input-Output Table for China, Japan, and Korea, 2005.' Data file accessed on October 25, 2015 from: http://www.ide.go.jp/English/Data/Io/index.html.

International Energy Agency (IEA) (2012). World Energy Outlook 2012. International Energy Agency, Paris.

Irabien, A. and R.C. Darton (2016). Energy-water-food nexus in the Spanish greenhouse tomato production. Clean Techn. Environ. Policy, Vol. 18: 1307-16.

Karkacier, O. and Z.G. Goktolga (2005). Input-output analysis of energy use in agriculture. Energy Conversion and Management, Vol. 46: 1513-1521.

Kahrl, F. and D. Roland-Holst (2008). China’s water-energy nexus. Water Policy, Vol. 10: 51-65.

Kuroiwa, I. and H. Ozeki (2010). Intra-regional trade between China, Japan, and Korea: Before and after the financial crisis. Institute of Developing Economies, Discussion Paper No. 237

Leck, H., D. Conway, M. Bradshaw, and J. Rees (2015). Tracing the Water-Energy-Food Nexus:

Description, theory and practice. Geography Compass, Vol. 9 (No. 8): 445-460

Lee, Y. (2015). Land, carbon, and water footprints in Taiwan. Environmental Impact Assessment Review, Vol. 54: 1-8.

Lenzen, M., R. Wood, and T. Wiedmann (2010). Uncertainty analysis for multi-region input-output models - A case study of the UK's carbon footprint. Economic Systems Research, Vol. 22 (No. 1): 4363.

Lenzen, M. (2011). Aggregation versus disaggregation in input-output analysis of the environment. Economic Systems Research, Vol. 23 (No. 1): 73-89.

Lenzen, M., D. Moran, A. Bhaduri, K. Kanemoto, M. Bekchanov, A. Geschke and B. Foran (2013). International trade of scarce water. Ecological Economics, Vol. 94: 78-85.

Leontief, W. (1970). Environmental repercussions and the economic structure: An Input-Output approach. The Review of Economics and Statistics, Vol. 52 (No. 3): 262-271.

Li, X., K. Feng, Y. Siu, and K. Hubacek (2012). Energy-water nexus of wind power in China: The balancing act between CO2 emissions and water consumption. Energy Policy, Vol. 45: 440-448.

Liaoning Water Resource Bulletin. Liaoning Provincial Department of Water Resouces: Shenyang, 2011. Liu, X. and R. Mu (2016). Public environmental concern in China: Determinants and variations. Global Environmental Change, Vol. 37: 116-27.

Ministry of Land, Infrastructure, Transport, and Tourism of Japan. Accessed on November 29, 2015 from: http://www.mlit.go.jp/tochimizushigen/mizsei/hakusyo/H24/2-2s.pdf

Ministry of Land Transportation, Water Resources, and Policy Bureau of the Republic of Korea. Accessed on December 28, 2015 from: http://kosis.kr

Murrant, D., A. Quinn, and L. Chapman (2015). The water-energy nexus: future water resource availability and its implications on UK thermal power generation. Water and Environment Journal, Vol. 29: 307-319

Mirzabaev, A., D. Guta, J. Goedecke, V. Gaur, J. Börner, D. Virchow, M. Denich, and J. Braun (2015) Bioenergy, food security and poverty reduction: Trade-offs and synergies along the water-energy-food security nexus. Water International, Vol. 40 (No. 5-6): 772-790.

Nagano. "Fifth Plan on Conservation of Aquatic Environment in Nagano Prefecture Conservation of Aquatic Environment.” Accessed on November 29, 2015 from: http://www.pref.nagano.lg.jp/mizutaiki/kurashi/shizen/mizukankyo/sogokekaku/5ji/documents/5th1.pdf National Bureau of Statistics of China. China Statistical Yearbook 2006. Accessed on May 10, 2017 from: http://www.stats.gov.cn/tjsj/ndsj/2006/indexeh.htm

Niigata. "Niigata Provincial Statistics.” Accessed on November 29, 2015

from: http://www.pref.niigata.lg.jp/HTML_Article/wp4,0.pdf

Okadera, T., M. Watanabe, and K. Xu (2006). Analysis of water demand and water pollutant discharge using a regional input-output table: An application to the city of Chongqing, upstream of the Three Gorges Dam in China. Ecological Economics, Vol. 58: 221-237. 
Pempel, T.J., ed. (2013). Politics in Asia: Economy-Security Nexus in Northeast Asia. Florence, KY, USA: Routledge.

Pfister, S., A. Koehler, and S. Hellweg (2009). Assessing the environmental impacts of freshwater consumption in LCA. Environmental Science \& Technology, Vol. 43 (No. 11): 4098-4104.

Pfister, S., D. Saner, and A. Koehler (2012). The environmental relevance of freshwater consumption in global power production. Int. J. Life Cycle Assess, Vol. 16:580-591

Pradeleix, L., P. Roux, S. Bouarfa, B. Jaouan, Z. Lili-Chabaane, and V. Bellon-Maurel (2015). Environmental impacts of contrasted groundwater pumping systems assessed by life cycle assessment methodology: Contribution to the Water-Energy Nexus study. Irrigation and Drainage, Vol. 64: 124138.

Rees, W.E. (1992). Ecological footprint and appropriated carrying capacity: What urban economics leaves out. Environ. Urban., Vol. 4: 121-130.

Research and Statistics Department, Minister's Secretariat Ministry of Economy, Trade and Industry of Japan. Accessed on November 29, 2015 from: http://www.meti.go.jp/statistics/tyo/kougyo/result-2.html Ringler, C., A. Bhaduri, and R. Lawford (2013). The nexus across water, energy, land and food (WELF): Potential for improved resource use efficiency? Curr. Opin. Environ. Sustain., Vol. 5:617-24.

Ringler, C., D. Willenbockel, N. Perez, M. Rosegrant, T. Zhu, and N. Matthews (2016). Global linkages among energy, food and water: economic assessment. J. Environ Stud Sci, Vol. 6:161-71.

Sanders, K.T. and S.F. Masri (2016). The energy-water agriculture nexus: The past, present and future of holistic resource management via remote sensing technologies. Journal of Cleaner Production, Vol. 117: 73-88.

Scott, C.A., A.P. Suzanne, M.J. Pasqualetti, A.L. Jones, B.E. Montz, and J.H. Hoover (2011). Policy and institutional dimensions of the water-energy nexus. Energy Policy, Vol. 39: 6622-6630.

Shizuoka. "Current State of Water Resources in Shizuoka Prefecture.” Accessed on November 29, 2015 from: http://www.pref.shizuoka.jp/kankyou/ka-060/mizu-genkyou.html

Siddiqi, A. and L.D. Anadon, (2011). The water-energy nexus in Middle East and North Africa. Energy Policy, Vol. 39: 4529-4540.

Statistics Bureau of Japan, Ministry of Internal Affairs and Communications (2005). "Population, Population Change (2000-2005), Area and Population Density.” Accessed on November 29, 2015 from: http://www.stat.go.jp/english/index.htm

Statistics Korea (KOSTAT) (2005). "Population, Households and Housing Units”. Accessed on May 10, 2017

from: http://kosis.kr/eng/statisticsList/statisticsList 01List.jsp?vwcd=MT ETITLE\&parentId=A\#SubC ont

Statistics Korea (KOSTAT) (2014). Explore Korea through Statistics 2014. Government Complex

Daejeon, 189 Cheongsa-ro, Seo-gu, Daejeon, Republic of Korea

Steen-Olsen, K., A. Owen, E.G. Hertwich and M. Lenzen (2014) Effects of sectoral aggregation on CO2 multipliers in MRIO analyses. Economic Systems Research, Vol. 26 (No. 3): 284-302.

Suh, S., M. Lenzen, G.J. Treloar, H. Hondo, A. Horvath, G. Huppes, O. Jolliet, U. Klann, W. Krewitt, Y. Moriguchi, J. Munksgaard and G. Norris (2004) System boundary selection in Life-Cycle inventories using hybrid approaches. Environmental Science \& Technology, Vol. 38 (No. 3): 657-664.

Tan, C. and Q. Zhi (2016). The energy-water nexus: A literature review of the dependence of energy on water. Energy Procedia, Vol. 88: 277-84.

Tukker, A. and E. Dietzenbacher (2013). Global multiregional input-output frameworks: An introduction and outlook. Economic Systems Research, Vol. 25 (No. 1): 1-19.

United Nations Framework Convention on Climate Change (UNFCCC) (2017). Accessed on May 5, 2017 from: http://www.ipcc.ch/publications_and_data/ar4/wg1/en/ch2s2-10-2.html.

United States Department of Agriculture (USDA) (2006a). “Cotton: World Markets and Trade.” Foreign Agricultural Service. Circular Series FOP 12-06. December 2006.

United States Department of Agriculture (USDA) (2006b). “Grain: World Markets and Trade.” Foreign Agricultural Service. Circular Series FG 12-06. December 2006.

United States Department of Agriculture (USDA) (2006c). "Livestock and Poultry: World Markets and Trade.” Foreign Agricultural Service. Circular Series DL\&P 2-06. October 2006. 
United States Department of Agriculture (USDA) (2008a). “Tree Nuts: World Markets and Trade.”

Foreign Agricultural Service. Circular Series. November 2008.

United States Department of Agriculture (USDA) (2008b). "Stone Fruit: World Markets and Trade.”

Foreign Agricultural Service. July 2008.

United States Department of Agriculture (USDA) (2009). "Fresh Deciduous Fruit (Apples, Pears, and

Grapes): World Markets and Trade.” Foreign Agricultural Service. June 2009.

United States Environmental Protection Agency (USEPA) (2017). Accessed on April 25, 2017

from: https://www.epa.gov/climate-indicators/greenhouse-gases

Ibid. Accessed on April 25, 2017 from: https://www.epa.gov/so2-pollution/sulfur-dioxide-

basics\#whatisso2

Vanham, D. (2016). Does the water footprint concept provide relevant information to address the waterfood-energy-ecosystem nexus? Ecosystem Services, Vol. 17: 298-307.

Vieira, A.S. and E. Ghisi (2016). Water-energy nexus in low-income houses in Brazil: The influence of integrated on-site water and sewage management strategies on the energy consumption of water and sewerage services. Journal of Cleaner Production, Vol. 133: 145-162

Vilanova, M., R. Nogueira, and J. Balestieri (2015). Exploring the water-energy nexus in Brazil: The electricity use for water supply. Energy, Vol. 85: 415-432

Walker, M.E., Z. Lv, and E. Masanet (2013). Industrial Steam Systems and the Energy-Water Nexus. Environ. Sci. Technol., Vol. 47: 13060-13067

Wang, Y., A. Geschke, and M. Lenzen (2015). Constructing a time series of nested Multi-Region InputOutput Tables. International Regional Science Review: 1-24.

Wenz, L., S.N. Willner, A. Radebach, R. Bierkandt, J.C. Steckel, and A. Levermann (2015). Regional and sectoral disaggregation of Multi-Regional Input-Output Tables - A flexible algorithm. Economic

Systems Research, Vol. 27 (No. 2): 194-212.

Wichelns, D. (2017). The water-energy-food nexus: Is the increasing attention warranted, from either a research or policy perspective? Environmental Science \& Policy, Vol. 69: 113-23.

Wiedmann, T. (2009). A review of recent multi-region input-output models used for consumption-based emission and resource accounting. Ecological Economics, Vol. 69: 211-222.

Wiedmann, T., H.C. Wilting, M. Lenzen, S. Lutter, and V. Palm (2011). Quo Vadis MRIO?

Methodological, data and institutional requirements for multi-region input-output analysis. Ecological Economics, Vol. 70: 1937-1945.

Wong, K.V. and C. Pecora (2015). Recommendations for Energy-Water-Food Nexus problems. Journal of Energy Resources Technology, Vol. 137: 1-5

World Bank (2007). An East Asian Renaissance, Ideas for Economic Growth. Washington, D.C.: The

International Bank for Reconstruction and Development/The World Bank.

World Economic Forum (WEF) (2008). Thirsty energy: Water and energy in the $21^{\text {st }}$ century. Energy

Vision Update 2009.

World Economic Forum (WEF) (2011). Water Security: The Water-Food-Energy-Climate Nexus. The

World Economic Forum Water Initiative. Island Press: Washington, DC.

World Factbook. Accessed on April 16, 2016: https://www.cia.gov/library/publications/the-world-

factbook/geos/ja.html

World Input-Output Database (WIOD). Accessed on October 1, 2015

from: http://www.wiod.org/new_site/database/niots.htm

Yillia, P.T. (2016). Water-Energy-Food nexus: framing the opportunities, challenges and synergies for implementing the SDGs. Österr Wasser-und Abfallw, Vol. 68: 86-98

YRCC Yellow River Water Resource Bulletin. Accessed on June 16, 2015

from: http://www.yellowriver.gov.cn/other/hhgb/2007.htm.

Yu, Y., K. Feng, and K. Hubacek (2014). Tele-connecting local consumption to global land use. Global Environmental Change, Vol. 23 (No. 5): 1178-1186.

Yunling, Z. (2010). China and Asian Regionalism. World Scientific Publishing Co. Pte. Ltd.: New Jersey. Zhang, X. and V.V. Vesselinov (2017). Integrated modeling approach for optimal management of water, energy and food security nexus. Advances in Water Resources, Vol. 101: 1-10. 
Zimmerman, R., Q. Zhu, and C. Dimitri (2016). Promoting resilience for food, energy, and water interdependencies. J. Environ. Stud. Sci., Vol. 6: 50-61. 


\section{Supporting Information}

\section{Sectoral Matrix}

\begin{tabular}{|c|c|c|c|}
\hline \multicolumn{2}{|r|}{15 Sector Classification } & \multicolumn{2}{|r|}{76 Sector Classification of the 2005 AlO Table } \\
\hline Code & Description & Code & Description \\
\hline \multicolumn{4}{|c|}{ Intermediate Sectors } \\
\hline \multirow{7}{*}{1} & \multirow{7}{*}{ Agriculture, livestock, forestry and fishery } & 001 & Paddy \\
\hline & & 002 & Other grain \\
\hline & & 003 & Food crops \\
\hline & & 004 & Non-food crops \\
\hline & & 005 & Livestock and poultry \\
\hline & & 006 & Forestry \\
\hline & & 007 & Fishery \\
\hline \multirow{4}{*}{2} & \multirow{4}{*}{ Mining and quarrying } & 008 & Crude petroleum and natural gas \\
\hline & & 009 & Iron ore \\
\hline & & 010 & Other metallic ore \\
\hline & & 011 & Non-metallic ore and quarrying \\
\hline \multirow{3}{*}{3} & \multirow{3}{*}{ Wearing apparel and other made-up textile products } & 020 & Knitting \\
\hline & & 021 & Wearing apparel \\
\hline & & 022 & Other made-up textile products \\
\hline \multirow{7}{*}{4} & \multirow{7}{*}{$\begin{array}{l}\text { Other non-electrical consumption products for daily- } \\
\text { use }\end{array}$} & 013 & Fish products \\
\hline & & 014 & Slaughtering, meat products and dairy products \\
\hline & & 015 & Other food products \\
\hline & & 016 & Beverage \\
\hline & & 017 & Tobacco \\
\hline & & 023 & Leather and leather products \\
\hline & & 025 & Wooden furniture \\
\hline \multirow{22}{*}{5} & \multirow{22}{*}{ Basic industrial materials } & 012 & Milled grain and flour \\
\hline & & 018 & Spinning \\
\hline & & 019 & Weaving and dyeing \\
\hline & & 024 & Timber \\
\hline & & 026 & Other wooden products \\
\hline & & 027 & Pulp and paper \\
\hline & & 028 & Printing and publishing \\
\hline & & 029 & Synthetic resins and fiber \\
\hline & & 030 & Basic industrial chemicals \\
\hline & & 031 & Chemical fertilizers and pesticides \\
\hline & & 032 & Drugs and medicine \\
\hline & & 033 & Other chemical products \\
\hline & & 034 & Refined petroleum and its products \\
\hline & & 035 & Plastic products \\
\hline & & 036 & Tires and tubes \\
\hline & & 037 & Other rubber products \\
\hline & & 038 & Cement and cement products \\
\hline & & 039 & Glass and glass products \\
\hline & & 040 & Other non-metallic mineral products \\
\hline & & 041 & Iron and steel \\
\hline & & 042 & Non-ferrous metal \\
\hline & & 043 & Metal products \\
\hline \multirow{3}{*}{6} & \multirow{3}{*}{ Computers and electronic equipment } & 050 & Electronic computing equipment \\
\hline & & 051 & Semiconductors and integrated circuits \\
\hline & & 052 & Other electronics and electronic products \\
\hline \multirow{2}{*}{7} & \multirow{2}{*}{ Automobiles } & 055 & Motor vehicles \\
\hline & & 056 & Motor cycles \\
\hline \multirow{2}{*}{8} & \multirow{2}{*}{ Industrial machinery } & 044 & Boilers, engines and turbines \\
\hline & & 045 & General machinery \\
\hline
\end{tabular}




\begin{tabular}{|c|c|c|c|}
\hline & & 046 & Metal working machinery \\
\hline & & 047 & Specialized machinery \\
\hline \multirow{2}{*}{9} & \multirow{2}{*}{ Household electrical appliance } & 049 & $\begin{array}{l}\text { Television sets, radios, audios and communication } \\
\text { equipment }\end{array}$ \\
\hline & & 053 & Household electrical equipment \\
\hline \multirow{6}{*}{10} & \multirow{6}{*}{$\begin{array}{l}\text { Other processed and assembled manufacturing } \\
\text { products }\end{array}$} & 048 & Heavy electrical equipment \\
\hline & & 054 & Lighting fixtures, batteries, wiring and others \\
\hline & & 057 & Shipbuilding \\
\hline & & 058 & Other transport equipment \\
\hline & & 059 & Precision machines \\
\hline & & 060 & Other manufacturing products \\
\hline \multirow{2}{*}{11} & \multirow{2}{*}{ Electricity, gas and water supply } & 061 & Electricity and gas \\
\hline & & 062 & Water supply \\
\hline \multirow{2}{*}{12} & \multirow{2}{*}{ Construction } & 063 & Building construction \\
\hline & & 064 & Other construction \\
\hline 13 & Trade & 065 & Wholesale and retail trade \\
\hline 14 & Transportation & 066 & Transportation \\
\hline \multirow{10}{*}{15} & \multirow{10}{*}{ Other services } & 067 & Telephone and telecommunication \\
\hline & & 068 & Finance and insurance \\
\hline & & 069 & Real estate \\
\hline & & 070 & Education and research \\
\hline & & 071 & Medical and health service \\
\hline & & 072 & Restaurant \\
\hline & & 073 & Hotel \\
\hline & & 074 & Other services \\
\hline & & 075 & Public administration \\
\hline & & 076 & Unclassified \\
\hline
\end{tabular}

